This item was submitted to Loughborough's Research Repository by the author.

Items in Figshare are protected by copyright, with all rights reserved, unless otherwise indicated.

\title{
Entrepreneurial orientation, competitive advantage and strategic knowledge management capability in Malaysian family firms
}

\section{PLEASE CITE THE PUBLISHED VERSION}

https://doi.org/10.1108/JKM-09-2020-0693

\section{PUBLISHER}

Emerald Publishing Limited

\section{VERSION}

AM (Accepted Manuscript)

\section{PUBLISHER STATEMENT}

This paper was accepted for publication in the journal Journal of Knowledge Management and the definitive published version is available at https://doi.org/10.1108/JKM-09-2020-0693. This author accepted manuscript is deposited under a Creative Commons Attribution Non-commercial 4.0 International (CC BY-NC) licence. This means that anyone may distribute, adapt, and build upon the work for non-commercial purposes, subject to full attribution. If you wish to use this manuscript for commercial purposes, please contact permissions@emerald.com

\section{LICENCE}

CC BY-NC 4.0

\section{REPOSITORY RECORD}

Mostafiz, Md Imtiaz, Mathew Hughes, and Murali Sambasivan. 2021. "Entrepreneurial Orientation, Competitive Advantage and Strategic Knowledge Management Capability in Malaysian Family Firms". Loughborough University. https://hdl.handle.net/2134/14828262.v1. 


\title{
Entrepreneurial Orientation, Competitive Advantage and Strategic Knowledge Management Capability in Malaysian Family Firms
}

\author{
Md Imtiaz Mostafiz (corresponding author) \\ Sheffield Business School, Sheffield Hallam University, UK \\ Mathew (Mat) Hughes \\ School of Business and Economics, Loughborough University, UK \\ Murali Sambasivan \\ Thiagarajar School of Management, Madurai, India

\begin{abstract}
Accepted for publication at Journal of Knowledge Management DOI: $10.1108 / J K M-09-2020-0693$
\end{abstract}

\begin{abstract}
Purpose - We test the thesis that the family firm's success hinges on effective strategic knowledge management (SKM) capability coupled with an entrepreneurial orientation (EO). Contingency theory holds that entrepreneurial success is contingent on strategic capabilities, and resource orchestration theory explains how well family firms nurture capabilities to structure, bundle, and leverage resources that define competitive advantage. This study combines these two theoretical viewpoints to propose the effects of EO and SKM capability on competitive advantage (CA) to achieve successful performance in family firms.

Design/methodology - We employ a hybrid approach applying structural equation modelling (SEM) and deep-learning artificial intelligence (DL-AI) analysis to survey data on 268 Malaysian family firms.

Findings - SEM results confirm that CA mediates the relationship between innovativeness, proactiveness, and risk-taking dimensions of EO and firm performance. Autonomy and competitive aggressiveness have no bearing, however. The relationships among innovativeness, proactiveness, and risk-taking with $\mathrm{CA}$ and performance are positively moderated by SKM capability, becoming more potent at higher levels. Moreover, four additional DL-AI models reveal the necessity of specific EO dimensions and the interacting effects of EO-SKM capability to influence CA and to attain performance success subsequently.

Originality/value - We theorize and present two new boundary conditions to a knowledge-based theory of the family firm and its firm performance. First, CA mediates the relationship between EO and performance, and second, strategic knowledge management capability moderates the relationships between EO and CA and between EO and family firm performance. Methodologically, we employ DL-AI to embrace non-linearity and prioritize predictor variables based on normalized importance to produce greater accuracy over regression analysis. Hence, DL-AI adds methodological novelty to the knowledge management and family firm literature.
\end{abstract}

Keywords: entrepreneurial orientation; strategic knowledge management capability; neural network; deep-learning artificial intelligence analysis; Malaysian family firms; family ownership 


\section{Introduction}

Uniting entrepreneurial behaviour with knowledge resources (Cabrilo and Dahms, 2018; Hughes et al., 2018b) is essential to competitiveness in evermore complex markets (Hughes et al., 2007, 2018a). The family firm is no exception (Herrero and Hughes, 2019). Family firms hold a unique potential to form knowledge-based advantages that cannot be duplicated by nonfamily counterparts (Patel and Fiet, 2011). As Sanchez-Famoso et al. (2015) define, a family firm is "an organization in which a family is involved in ownership, with the impact of this involvement on business and innovation activities occurring through a combination of knowledge sharing, networks, family corporate identity, values, dynamics, and heritage" (p. 241). Family firms exhibiting an entrepreneurial orientation (EO) (Cruz and Nordqvist, 2012) are forward-looking (Casillas et al., 2011). They can act opportunistically owing to their tendency to hold internal financial resource stocks and patient capital (Boling et al., 2016). EO is defined as the firm's processes, practices, and decision-making styles commensurate with entrepreneurship (Short et al., 2009). However, we know little about galvanizing EO among family firms to (re)vitalize competitiveness and grow firm performance (see Table I). For instance, while bearing an EO is considered paramount among family firms (Arzubiaga et al., 2018), merely having an EO is not sufficient for long-term success (Wales et al., 2020). Contemporary research identifies the firm's ability to leverage associated knowledge resources (Hughes et al., 2018b, 2021) as an essential boundary condition to the utility of an EO. Effective use of knowledge resources can close the gap between EO as a strategic posture and EO as a benefactor of family firm performance. Nevertheless, differences in knowledge management capability have so far escaped study. As Calabrò et al. (2020) argue, heterogeneities between EO and family firm performance arise from the omission of contingency variables. The majority of prior research consider only family- 
oriented variables as contingencies (see Table 4 in Hernández-Linares and López-Fernández (2018)), overlooking strategic and knowledge management variables. The conversation on EO in family firms does not require more consideration of family-specific variables. Instead, the contingency effects of strategic and knowledge management variables between EO and performance among family firms warrant urgent investigation (Hernández-Linares and LópezFernández, 2018) if we are to understand how, when and why EO benefits (or not) family firms, and heterogeneities among family firms themselves.

We take as our vantage point the concept of strategic knowledge management (SKM) capability. SKM capability is defined as a set of activities representing the ability of the firm to implement decisions into productive actions through a formalized process of creating, bundling, storing, and using new and existing knowledge resources (Cabrilo and Dahms, 2018; Gold et al., 2001). Effective knowledge utilization activities are pivotal among family firms (Dotsika and Patrick, 2013). Family firms with excellent knowledge management can possess "combinative capabilities" that facilitate new forms of competitive advantage (Patel and Fiet, 2011). To generate a thorough knowledge-based theory of the family firm, we propose that EO and SKM capability together set the attributes family firms need for competitive advantage (CA) and excellent firm performance. While EO in isolation is not enough for sustained performance among family firms (Hernández-Linares and López-Fernández, 2018), neither is an SKM capability (Cabrilo and Dahms, 2018). For example, Heisig et al. (2016) set out that SKM capability must be amplified by other strategic actions (e.g., entrepreneurship) to utilize knowledge resources fully. In turn, SKM capability can intensify the firm's ability to gain and sustain CA from its strategic behaviours. As a strategic orientation, we propose that variation in EO can lead family firms into high-risk, innovative, and proactive efforts that are not matched by 
an ability to convert these high-risk and uncertain investments into wealth. Therefore, we argue that CA, defined as the "ability of the firm to create unique advantages and to protect these advantages against imitation" (Grant, 1996, p. 380), will mediate the relationship between EO and family firm performance as CA facilitates the creation of a defensible position over competitors (Li et al., 2006). Concurrently, SKM capability concentrates on the processes that amplify knowledge-based strategies by increasing innovation activities' effectiveness and efficiency (Heisig et al., 2016). Therefore, we see an SKM capability as the missing link in converting EO into CA and superior performance among family firms. To date, the family firm literature has not profoundly considered its reliance on an EO (Arzubiaga et al., 2018; Hughes et al., 2018) and has underestimated the family firm's capability to use available knowledge in favour of a focus on knowledge accumulation or transmission (Chirico, 2008). We close these research gaps to advance a knowledge-based theory of the family firm and ask: (1) To what extent does achieving competitive advantage mediate the relationships between entrepreneurial orientation and family firm performance? (2) Does the family firm's strategic knowledge management capability affect whether it achieves competitive advantage and firm performance from its entrepreneurial orientation?

To answer these research questions, we use the contingency perspective of EO (Kearney et al., 2018; McKenny et al., 2018) together with resource orchestration theory (Sirmon et al., 2007; Sirmon et al., 2011). We test our thesis against a dataset of 268 Malaysian family firms in a resource-scarce economy (Falahat et al., 2018). We do not assume a universal performance benefit from each EO dimension among family firms (Hernández-Linares and López-Fernández 2018; Hughes and Morgan, 2007; Lumpkin and Dess, 1996). First, acknowledging the knowledge-based resource-dependency of EO (Hughes et al., 2007, 2018b), we theorize that 
sustainable CA driven by EO mediates the relationship between EO and family firm performance. We provide a new boundary condition to explain how family firms benefit (or not) from implementing the various dimensions of EO. In doing so, we explain why family firms struggle to service any benefit from EO (see Table I). Second, as a resource orchestrating mechanism, SKM capability provides a motor by which family firms can create much-needed idiosyncratic capabilities (Cerchione et al., 2016) to mobilize, implement and leverage knowledge resources. Specific dimensions of EO couple with family firms' SKM capability to increase firm performance, providing a second new boundary condition to explain when family firms benefit (or not) from manifesting EO and its dimensions.

We provide three main contributions to family business literature. First, our study responds to several calls to investigate EO in conjunction with strategic capability among family firms (Calabrò et al., 2020; Hernández-Linares and López-Fernández, 2018; Hughes et al., 2018b). We unpack the composition of EO and allow its dimensions to interact with SKM capability. The family firm literature is yet to critically examine EO's individual dimensions (Arzubiaga et al., 2019; Zellweger and Sieger, 2012) or assert the contingency role of knowledge management processes (Cerchione et al., 2016). By revealing the moderating effects of SKM capability on the EO-CA and EO-performance relationships, we advance a knowledge-based theory of the family firm to explain when family firms profit from an EO and why differences in performance are found among family firms. Second, family firms are accustomed to operating defensively (Hernández-Linares and López-Fernández, 2018). Our study provides additional depth to a knowledge-based theory of the family firm by demonstrating how SKM capability matters for specific EO dimensions. Third, we reveal the previously hidden role of CA as a mediating variable between $\mathrm{EO}$ and family firm performance. By revealing the mediating role of 
CA, we provide a new explanation for when a relationship between EO and firm performance exists for family firms. Finally, as a methodological contribution, we provide a new hybrid statistical approach consisting of structural equation modelling (SEM) and feed-forward-backpropagation multi-layer perceptron deep-learning artificial intelligence (DL-AI) analysis. DL-AI includes in-depth scrutiny of the potential for non-linearity in a theoretical model by detecting hidden relationships between criteria and predictor variables (Sim et al., 2014). Because SEM can result in hypotheses to be incorrectly unsupported due to problems (such as interdependence and constant variance of the error $(\varepsilon)$ term) (Detienne, Detienne, and Joshi, 2003) with exogenous and endogenous variables, the DL-AI program searches for and learns hidden layers between an input layer (akin to independent variables) and an output layer (akin to a dependent variable) to capture non-linear relationships between the predictor and outcome variables in ways that SEM or multiple regression analysis simply cannot achieve. Coupling DL-AI analysis to SEM helps ensure that our results are accurate and reliable to serve as a launchpad for a knowledge-based theory of the family firms.

\section{Theoretical lens and hypotheses development}

\subsection{Entrepreneurial orientation and family firm performance}

Lumpkin and Dess (1996) propose that firms achieve EO by configuring entrepreneurial behaviours around innovativeness, proactiveness, risk-taking, competitive aggressiveness, and autonomy dimensions. While the first three dimensions are commonplace among EO studies, autonomy is potentially indispensable for family firms because of their emphasis on organizational processes and structural choices that unleash family power (Akhtar et al., 2015; Zellweger and Sieger, 2012). Also, family firms potentially require competitive aggressiveness (Short et al., 2009) to defend existing activities against competitive threats while exercising 
decision rights to dispose or grow its asset base flexibly. Autonomy and competitive aggressiveness are also crucial in an emerging economy context (Boso et al., 2013). Therefore, we consider the five-dimension view of EO essential to an accurate depiction of what it means for these family firms to be entrepreneurial.

Innovativeness refers to the degree of organizational commitment to creativity and experimentation of new ideas to develop new products, services, and processes (Lumpkin and Dess, 1996). Proactiveness encompasses a firm's ability to seize initiatives related to market opportunity by implementing innovation ahead of competitors and market changes (Morris et al., 2011). Risk-taking refers to the willingness to depart from routine organizational activities and take bold actions such as venturing into new markets and making risky resource commitments to initiatives with uncertain outcomes (Wiklund and Shepherd, 2011). Competitive aggressiveness exerts forceful responses and a combative posture to outperform competitors (Lumpkin and Dess, 2001). Autonomy aims at "bringing forth a business concept or vision and carrying it through to completion" (Lumpkin and Dess, 2010, p. 431).

Despite its purported benefits, differences in manifesting and benefiting from EO are apparent among family firms (see Table I). For instance, family firms are more cautious about risk-taking (Naldi et al., 2007), which leads these family firms to favour incremental innovation over radical innovation (Gómez-Mejía et al., 2007; Hu and Hughes, 2020). These differences are not limited to innovativeness either. For example, some studies report mixed effects from autonomy on firm performance (Casillas and Moreno, 2010) and non-significant effects from innovativeness, proactiveness, and risk-taking (Garcés-Galdeano et al., 2016; Madison et al., 2014). Other studies, however, report some positive effects from EO or its dimensions on family firm performance (Arzubiaga et al., 2019; Calabrò et al., 2020; Campbell and Park, 2018). The 
performance benefits of manifesting $\mathrm{EO}$ and its dimensions among family firms are inconclusive. While these differences could be due to how firm performance is measured (McKenny et al., 2018), the scale of these differences indicates that unknown variables intervene in the relationship between EO and family firm performance. To date, prior research has prioritized (almost exclusively) family-oriented variables as contingencies (see Table 4 in Hernández-Linares and López-Fernández, 2018, for a comprehensive illustration). Instead, grounding ourselves in the contingency perspective of EO (Kearney et al., 2018) and resource orchestration theory (Sirmon et al., 2007, 2011), we anticipate that strategy variables explain when (mediating) and knowledge management variables explain to what extent (moderating) EO dimensions affects family firm performance.

[Insert Table I about here]

We first theorize that the extent to which firms' use of EO dimensions manifests superior family firm performance is explained by how effectively the family firm realizes CA from its entrepreneurial endeavours. The purposes and outcomes of CA and firm performance are distinct and operationalized separately. We follow Covin and Wales (2019) and foretell that the sheer differences in findings of whether EO dimensions affect firm performance is explained by the fact that EO and firm performance are long-linked. We predict that the effectiveness of the family firm in realizing CA explains the reason for the EO-performance relationship to exist (mediation). We further predict that the extent to which the family firm builds an SKM capability influences the relationship between $\mathrm{EO}$ dimensions and $\mathrm{CA}$ and between $\mathrm{EO}$ and firm performance (moderation).

\subsection{Entrepreneurial orientation, competitive advantage, and firm performance}


EO encompasses strategic decision-making activities to introduce new product-services and reshape organizational philosophies and behaviours around entrepreneurism (Wales et al., 2020). EO can then provide the resource-based ingredients, or the building blocks, for sustainable CA (Rauch et al., 2009). CA then captures the extent to which firms triumph in effectuating their goals. CA is distinct from firm performance (Li et al., 2006) in that CA represents the resource-orchestrated conversion of organizational behaviours into unique properties that can fuel firm performance. Without that conversion, entrepreneurial endeavours risk being unproductive or inefficient. $\mathrm{CA}$ is achieved through sustaining lower prices, increasing the quality of offerings, diversification, service flexibility, delivery dependability, faster time-tomarket, new production facilities, improved customer services, and the incorporation of superior innovation to outperform competitors (Li et al., 2006; Tracey et al., 1999). Firm performance is the outcome of these strategic successes in which firms experience increases in profitability, operational performance, market share, and overall firm performance (McKenny et al., 2018). Due to the multifaceted nature of firm performance, the relationship between the dimensions of EO and CA warrants nuanced investigation (Covin and Wales, 2019; Wales et al., 2020).

Concerning innovativeness, family firms may come across innovations that exceed their ability to implement effective strategies, risking extreme losses (Singh and Fleming, 2010; Taylor and Greve, 2006). For instance, firms (especially knowledge-intensive ones) tend to absorb resources from existing firm activities in the process of experimenting with new product development (Hughes et al., 2021; Wiklund and Shepherd, 2011). Manifesting the innovativeness dimension of EO consumes many resources and, therefore, does so continuously while in use (Yin et al., 2020). For family firms in a resource-scarce economy, this resource hunger will almost certainly harm firm performance if it fails first to generate CA. 
Innovativeness provides a vital launchpad for creating initiatives for competitive advantage, however. For example, Hughes et al. (2010) demonstrate that investments into innovation strategy can help a new venture realize cost and differentiation advantages. Innovativeness sets in place routines for creativity and experimentation that develop and upgrade existing products to assert temporary competitive advantages while setting a longer-term emphasis on new product breakthroughs for longer-term advantage (Hughes et al., 2021). Innovativeness is then central to the adaptive fitness and health of the firm (March, 2006) because of its potential to generate and renew competitive advantage first and foremost. We, therefore, predict that CA mediates the relationship between innovativeness and family firm performance.

In family firms, proactiveness represents a tendency to detect emerging opportunities and act early to pursue a first-mover advantage by introducing new products or services before competitors (Jiménez-Jiménez et al., 2020). This implies that a family firm only succeeds financially when converting proactive initiatives into a more substantial CA (Bauweraerts and Colot, 2017). For example, proactiveness characterizes opportunity-seeking behaviour (Hughes et al., 2021). The family firm will act with vision and initiative on opportunities that are not yet fully formed (Short et al., 2009). Inevitably then, the proactiveness dimension activates new market scoping, searching and prospecting to commit resources to enter new markets. Proactiveness drives long-term gambles on latent market needs, which may or may not bring financial success (Slater and Narver, 1998). Indeed, scholars report that proactiveness is a poor predictor of family firm growth (Daily and Thompson, 1994). Conversely, greater levels of proactiveness improve the ability of the family firm to identify and forge first-mover advantages (Hughes and Morgan, 2007). Therefore, the extent to which these gambits reward firm performance should rely first on the firm's ability to craft advantageous positions in those 
nascent markets. We anticipate that CA mediates the relationship between proactiveness and family firm performance.

High risk-taking attitude echoes "uncertain and ambiguous knowledge recombination" (Patel et al., 2015, p. 1740), which can negatively affect the return on investment (Hill and Snell, 1989). The benefit of a risk-taking posture lies in its ability to compel refurbishment of competitive advantage. For instance, risk-taking is associated with greater tolerance of debt funding and the pursuit of new initiatives with unknown outcomes. Family firms do not take the risk as a strategy to increase firm performance directly but tolerate initiatives that may bear fruit in the longer term. For family firms, the focal point of the risk-taking activity is its implications for increasing or destroying family wealth (Sharma, Chrisman and Chua, 1997; Zahra et al., 2004) and jeopardizing its socio-emotional wealth (Gómez-Mejía et al., 2007). Prior studies suggest that these concerns can make family firms less entrepreneurial (e.g., Naldi et al., 2007; Uhlaner et al., 2012). However, because of the primacy of socio-emotional wealth in strategic decision-making, we expect that family firms will take controlled risk, acting in ways that will build on competitive advantage. Doing so, it protects the integrity and wealth of the family. Studies suggest that family firms prefer innovation strategies that carry controllable risk (e.g., investments in related or adjacent initiatives that can enhance or consolidate competitive advantage) (Scholes et al., 2021). Subsequent financial returns might be modest, but they will not exhibit the deep peaks and troughs possible when risk-taking is high but strategically uncontrolled. Therefore, we anticipate that the effectiveness of the family firm at creating or consolidating CA mediates the relationship between the risk-taking dimension and family firm performance. 
For autonomy, Martin and Lumpkin (2003) report a downward trend among successive family generations. Family firms tend to involve more family members in decision-making processes, and they appoint more family members to the board. The risks are a dichotomy in the family firm, defined by a situation in which family members possess autonomy and decision rights due to their family membership but reduced autonomy for non-family managers (Carney, 2005). Greater levels of organizational autonomy allow for many voices and ideas to be brought to bear business decisions and initiatives, diluting the family orientation lock that risks knowledge redundancy and echoing of poorly thought-through ideas (Herrero and Hughes, 2019). While potentially breeding conflict (Dyer, 2006), autonomy increases the willingness and an ability to investigate entrepreneurial possibilities (Burgelman, 1983), work independently to enact an entrepreneurial vision (Lumpkin and Dess, 1996), and champion new forms of advantage (Short et al., 2009). Autonomy can also leverage the knowledge recombination advantages of family firms (Patel and Fiet, 2011), consolidating a key promise of their CA over poorly organized peers and their non-family counterparts. For these reasons, the greater number and coordination of knowledge resources made possible by autonomy should strengthen CA as the explanation for any subsequent improvements in firm performance. CA should then mediate the relationship between the autonomy dimension and firm performance.

Competitive aggressiveness concerns devising and enacting strategies that defend the market position and combat competitive threats to the survival and prosperity of the firm (Smith, Ferrier and Grimm, 2001). Competitive aggressiveness includes activities to cut prices and sacrifice short-to-medium term profitability to shore up and increase market share (Venkatraman, 1989), or to invest more relative to competitors on customer acquisition (e.g., marketing), retention (e.g., quality) or market-serving (e.g., manufacturing) initiatives (MacMillan and Day, 
1987). A family firm will employ more aggressive competitive tactics when its continuation is threatened (e.g., Gómez-Mejía et al., 2007); that is, it will act aggressively to restore, renew, or increase its CA. Therefore, while seemingly an offensive posture, it is also a defensive one (Short et al., 2009). For instance, family firms tend to privilege survival and family employment more than maximizing profit or increasing market share (Athanassiou et al., 2002). A further effect of this mindset concerns dangers to its reputation. Family members closely involved in taking combative actions might harm the firm's image and reputation upon the failure of aggressive initiatives (Dyer Jr and Whetten, 2006). Therefore, we expect that competitive aggressiveness is oriented and directed towards embellishing competitive advantage as the primary condition for its survival. The exposure the aggressiveness dimension creates to new knowledge resources and market activities helps realize CA, which serves as the essential mechanism to explain subsequent rents benefiting firm performance.

From these arguments, we predict that those family firms better able to harness competitive advantages explains the relationships between EO dimensions and family firm performance. Thus:

Hypothesis 1: Competitive advantage mediates the relationship between the dimensions of EO (hla: proactiveness, hlb: innovativeness, hlc: risk-taking, hld: autonomy, and hle: competitive aggressiveness) and the performance of family firms.

\subsection{The contingency role of SKM capability}

Evidence of a positive EO-performance relationship among family firms is mixed, indicating that family firms are heterogeneous in their ability to capitalize on EO. One explanation is how they generate $\mathrm{CA}$ as the explanation for when EO creates family firm performance. However, we 
further theorize that differences in SKM capability among family firms further explain which family firms experience a stronger or weaker relationship between EO dimensions and CA and between EO and firm performance. SKM capability sets the ability to effectively and efficiently use the organization's knowledge resources through distinctive orchestration routines (Skyrme and Amidon, 1997; Zack 1999; Inkinen et al., 2015). Winter (2003) defines organizational capability as "a high-level of routine (or collection of routines) that, together with its implementing input flows, confers upon an organization's management a set of decision options for producing significant outputs of a particular type.” (p. 991). In this view, SKM capability augments firms with processes that improve resource orchestration. Firms that are more prone to suffer from resource-related liabilities (such as family firms (Muñoz-Bullón and Sanchez-Bueno, 2011)) can efficiently and effectively structure, bundle, and leverage their resources to strengthen value creation (CA) and wealth creation (performance) initiatives.

When EO dimensions are low, a stronger SKM capability should strengthen how much $\mathrm{CA}$ is realized from the few entrepreneurial opportunities it encounters. A low level of innovativeness in the family firm may not generate a sufficient quality or quantity of new possibilities or market-oriented activities. A low level of innovativeness discourages new experimentations, innovations, and value-creating actions. Therefore, such a family firm must make the best use of the few innovative initiatives it produces if it is going to achieve more CA from less innovative input. To do this, it must have a high SKM capability to bring knowledge resources to bear to filter out poor initiatives and augment those with the most potential. Concurrently, the family firm with low risk-tolerance will not act on innovative initiatives unless they possess and can intelligently apply knowledge resources to realize advantages from its few innovative initiatives. Similarly, for limited proactive, autonomous, or defensive initiatives to 
bear the most fruit, a strong SKM capability means that the family firm possesses knowledgebased distinctive competencies commensurate with knowledge processes that apply the most value-creating knowledge assets for CA creation (Carbilo and Dahms, 2018).

When EO dimensions are high, we expect SKM capability to be essential to how much CA materializes and prevent tenuous or unproductive initiatives from continuing. A high level of EO dimensions can collectively produce radical innovation outputs, which may exceed the firm's capacity to capitalize on those innovations productively. For example, a high level of risk-taking, innovativeness, and proactiveness means that a family firm will aggressively identify and introduce forward-looking, future-oriented innovations in advance of competitors, in advance of a formal market establishing, and with highly uncertain outcomes. This approach is dangerous to any business with limited resources (Hughes et al., 2021; Muñoz-Bullón and Sanchez-Bueno, 2011). In this situation, poor execution will result in no CA or second-mover advantages for competitors. To ensure such initiatives are intelligent and well-executed, the family firm with a more compelling SKM capability can generate, assimilate, and apply knowledge resources (Martinez-Conesa et al., 2017) to realize more CA latent in entrepreneurial initiatives. Without a sufficient SKM capability, family firms will exhibit much less knowledge sharing and be more prone to initiatives failing (e.g., Zahra et al., 2007). In these events, family firms that concurrently possess strong SKM capabilities are far more likely to realize competitive advantages from their EO initiatives. A high level of EO dimensions also increases new market entry frequencies and aggressive competitive tactics (Lumpkin and Dess, 1996). Those family firms with greater SKM capability possess more advanced search and selection processes to extract CA from entrepreneurial initiatives. Without SKM capability, family firms will be unable to harvest and apply knowledge resources effectively. Therefore, when EO dimensions are high, 
the probability of competitive deficiencies (not advantages) from poorly executed initiatives is high in whatever combination. Thus:

Hypothesis 2: SKM capability positively moderates the relationship between the dimensions of EO (h2a: proactiveness, h2b: innovativeness, h2c: risk-taking, h2d: autonomy, and h2e: competitive aggressiveness) and CA of family firms.

EO provides the mobilizing vision to structure, bundle, and leverage resources to pursue new initiatives that carry wealth-creating potential (Chirico et al., 2011). However, "an unbridled EO may blind the firm into the erroneous belief that technological superiority is a sufficient condition for new product success" (Atuahene-Gima and Ko, 2001, p. 56). Therefore, knowledge capabilities are essential to refining and sharpening entrepreneurial initiatives. A poor SKM capability increases the chances that weak, tenuous, or unproductive entrepreneurial initiatives will be invested in, prioritizing market intelligence selectively and symbolically to satisfy their entrepreneurial efforts and ultimately squandering potential returns to firm performance. A stronger SKM capability enables better, more accurate, and timelier knowledge resources to be brought to bear on entrepreneurial initiatives, strengthening the contributions of EO dimensions to firm performance.

A high level of proactiveness can lead to the bundling of product market offerings driven by technological novelty and weak market visions instead of signals by established consumeroriented markets (Wales et al., 2013b), risking firm performance. Profiting from consumermarket needs requires entrepreneurial firms to implement innovative solutions intelligently. Competitive aggressiveness will certainly trigger retaliation from market rivals and incumbents. Liao et al. (2011) assert that firms must nurture SKM capability to assess and respond effectively 
to competitors' (re)actions. At high levels, autonomy risks employees championing their own initiatives in ways that distract from core business activity. While necessary to harvesting the support and resources needed to bring forth a business concept or vision and carrying it through to completion (Lumpkin and Dess, 1996), strong ownership controls (Carney, 2005) tend to lead to centralized information (Dyer and Handler, 1994) that reduce the effectiveness of autonomous initiatives. A strong SKM capability combats this tendency, enabling processes and routines for generating and sharing intellectual capital to enhance the application and utility of autonomous initiatives. Finally, risk-taking involves bets on initiatives with uncertain outcomes. Unregulated, the family firm risk descending into a failure trap when poorly judged risks are repeated to pursue the next breakthrough. While partly regulated by control tendencies in the family, family firms also rely heavily on internal family social capital generating a family orientation lock (Herrero and Hughes, 2019). New information rarely enters the family decision-making corpus in this situation. A strong SKM capability can offset the peril of a family orientation lock.

Based on these arguments, we predict that when coupled with a strong SKM capability, family firms can best orchestrate the knowledge resources needed to derive more firm performance from EO dimensions. Therefore:

Hypothesis 3: SKM capability positively moderates the relationship between the dimensions of EO (h3a: proactiveness, h3b: innovativeness, h3c: risk-taking, h3d: autonomy, and h3e: competitive aggressiveness) and the performance of family firms.

\section{Research methodology}

3.1 Research context, sample, and data collection 
We collected survey data from family firms operating in Malaysia's knowledge-intensive industries. The continuance of firms operating in knowledge-intensive industries (i.e., software, architecture, consultancy, where knowledge is the most pivotal resource) hinges on the effective use of knowledge resources (Turulja and Bajgorić, 2018; Tat and Hase, 2007). Moreover, these firms tend to exhibit EO properties to various extents (Falahat et al., 2018), making them especially suited for studying our theoretical model. The Malaysian National Innovation Survey 2018 reports that both manufacturing and service firms in knowledge-intensive industries are highly engaged in innovative activities. These activities include innovating manufacturing methods, developing services abetted by technological advancements, introducing new products and services and increasing R\&D practices (MOSTI, 2018). The Malaysian government is rigorously monitoring the project 'Creating A Knowledge-Based Economy', by undertaking various promotional policies (MTE, 2020) and pouring significant amount of resources into promoting firms' innovative activities (MASTIC, 2019). Also, the number of family-owned businesses is increasing in Malaysia (Zainol, 2013). Therefore, it is a suitable research context to test our theoretical model.

We selected sample firms from national directories of Malaysian entrepreneurs (MEDAC, 2018). To date, 29649 entrepreneurial firms are registered with MEDAC. To achieve our research objective, we selected sample firms operating in a knowledge-intensive industry (13598 firms) because the necessities to utilize knowledge effectively are much higher among firms in these industries (Turulja and Bajgorić, 2018; Tat and Hase, 2007). These industries include firms operating in aero components manufacturing, chemicals, minerals and alloy, pharmaceuticals, computer components, construction service, IT and software services, and data processing (MEDAC, 2018). We contacted these firms (randomly selecting 3000 firms) by 
telephone to verify their existence and willingness to participate in the research. We administered the questionnaire in English to those firms that agreed to participate in our research during the first wave. At this stage, we collected data on firm characteristics, EO and SKM capability from entrepreneurs. The 327 firms responded to our calls, equating to a response rate of 10.9 percent. We followed two criteria to determine their status as family firms. The operationalization of family firm status is measured by the "concentration of control within a single-family" (Zahra, 2012, p. 57). Therefore, first, we asked entrepreneurs about the percentage of the firm's capital (family ownership-share) held by the family and the percentage of management positions occupied by family members (Zahra, 2012). We considered a firm to qualify as a family firm when a single-family held 50 percent or more capital, and at least 50 percent of managerial positions were occupied by family members (Jiménez-Jiménez et al., 2020). In total, 276 firms qualified as family firms. After four months, we administered a second questionnaire to collect data on CA and firm performance from top managers (i.e., finance and operational managers) of these qualifying firms. We received 268 valid and completed responses for hypotheses testing (Hair et al., 2016) from the 276 qualified family firms. We followed Buccieri et al.'s (2019) approach to collect the data from key informants as required in the emerging economy context. In both the waves, we conducted a review of the data using an anonymous person (e.g., general manager/deputy general manager) to confirm data accuracy. This process helped us to control social desirability bias (Zahra and Covin, 1995). Furthermore, we examined for possible nonresponse bias via a $t$-test of the variables, comparing the first $7 \%$ of the dataset with the last $7 \%$ (in both waves) (Armstrong and Overton, 1977). We identified no statistically significant bias among the results. We also assessed informant competence on a five-point Likert scale (Heide and Weiss, 1995) in both the data collection waves. The mean values of 4.16 and 4.39, 
respectively, confirm that our informants were competent and knowledgeable enough to provide the necessary information.

\subsection{Measurement}

All items and their properties are reported in Appendix 2.

3.2.1 Dependent variable. Firm performance was measured by evaluating profitability (three

items) and sales performance (three items), with items sourced from Boso et al. (2013) and Menguc and Auh (2008). All items were measured through a subjective scale on a five-point Likert scale, ranging from $1=$ very low to $5=$ very high. Objective performance measure has the advantage of avoiding potential issues pertinent to self-assessment. In contrast, subjective measures provide a comprehensive and substantive view of firm performance as items can be phrased to compel comparison against competitors (Cruz-González et al., 2014). Moreover, subjective measures consist of various aspects of firm performance, providing more complete insights over objective indicators. Prior studies also evidence that subjective performance scales are strongly correlated with objective performance measures (Dess and Robinson, 1984; Powell, 1992; Sidhu et al., 2007). Due to reliable objective data being unavailable, Kirca (2011) suggests using subjective indicators over objective indicators in the emerging economy context.

3.2.2 Independent variable. We measured EO by its five sub-dimensions of innovativeness (five items), proactiveness (three items), risk-taking (three items), autonomy (three items) and competitive aggressiveness (three items). We sourced items from Jambulingam et al. (2005), Covin and Slevin (1989) and Hughes and Morgan (2007). We measured the sub-dimensions of the EO based on five-point Likert scales where ' 1 ' represents 'strongly disagree/very low', and '5' represents 'strongly agree/very high'. 
3.2.3. Mediating variable. CA was measured by five sub-dimensions, representing price/cost (two items), quality (four items), dependability (three items), customization (three items), and time-to-market (four items) (Li et al., 2006). The sub-dimensions of CA were measured on fivepoint Likert scales (' 1 ' represents 'strongly disagree/very low', and '5' represents 'strongly agree/very high').

3.2.4 Moderating variable. SKM capability measures (five items) were sourced from Boumarafi and Jabnoun (2008) and Cabrilo and Dahms (2018). Sample items include, "Our strategy is formulated and updated based on company knowledge and competencies"; "Our firm has knowledge and competence management strategy which is communicated to employees clearly and comprehensively". SKM capability was measured on five-point Likert scales where '1' represents 'strongly disagree/very low', and '5' represents 'strongly agree/very high'.

3.2.5 Control variables. We used five variables to control for other factors that may influence the results. We followed Cruz-González et al. (2014) to operationalize firm age and firm size as control variables. The natural logarithm of the number of employees was used to control for firm size. The natural logarithm of firm age was used to control for age. We requested that respondents provided information on environmental dynamism and munificence (Kreiser et al., 2013). Environmental dynamism was measured (five items) on a five-point Likert scale, sourced from Kreiser et al. (2013) and Miller and Friesen (1982). Sample items include predictability of competitors' actions, predictability of demand and consumer tastes, and the rate of technological change within the industry. We measured munificence using four items on a five-point Likert scale, sourced from Schultz et al. (1995) and Kreiser et al. (2013). Sample items include current profitability of the industry, projected profitability (5-years or more) of the industry, and projected long-term market growth rate (5-years and more). To capture possibly sensitivity to the 
ownership context of the family firm, we control for the number of family owners, measured as 'how many family members are involved in the ownership of the firm' (Scholes et al., 2021). Also, instead of controlling for how much ownership percentage the family holds, we include this instead as part of our post-hoc tests. It is measured by the percentage of share ownership held by the family and is categorized into two groups (50-75 per cent and 76-100 per cent).

\section{Analysis and results}

\subsection{Data characteristics and descriptive statistics}

Table II reports the correlations between constructs, mean, standard deviation, normality, and multicollinearity values. The skewness and kurtosis values show that the data are normally distributed. Also, the variance inflation factor (VIF) values represent a minimal level of multicollinearity among constructs. The results highlight that the sample firms are three to thirteen years old (mean 8.7) with an average of forty employees (minimum 17 and maximum 83 people; SD 7.2). One-hundred and fifty-two (152) firms operate in the manufacturing knowledge-intensive industry, and one-hundred and sixteen firms are operating in the serviceoriented knowledge-intensive industry. Demographic information is presented in Appendix 1.

[Insert Table II about here]

\subsection{Reliability and validity}

Table II presents the results of reliability and validity analyses. The Cronbach alpha values for all constructs are higher than 0.70, confirming internal consistency (Hair et al., 2016). The average variance extracted (AVE) values are higher than 0.50 for each contract. The square root of the AVE value (diagonal values in Table II) for each construct is also higher than the corresponding 
correlations. The standard loadings of the items are reported in Appendix 2. Standard loadings are higher than 0.70. Based on these results, we conclude that the measurement items used in this study are reliable and establish the constructs' convergent and discriminant validity (Fornell and Larcker, 1981).

[Insert Table III about here]

\subsection{Common method variance}

The informant-based survey data collection approach carries a risk of common method variance (CMV). We took several measures to mitigate this risk. First, we removed all barriers to psychological separation in the questionnaire to ensure that the respondents were not aware of the research goal (we also included other questions that were not used in this study) (Chang et al., 2010, Podsakoff et al., 2003). Second, we collected the data in two different timeframes. This data collection approach helped us control the threats of simultaneity and the ex-ante issue of endogeneity (Guide and Ketokivi, 2015). Also, we computed Harman's one-factor test, and the results represent that the percentage of variance explained by the first component is less than $50 \%$, accounted for $23.76 \%$. Finally, we conducted a more rigorous single latent factor analysis using AMOS 24. The results highlight that the fit indices are significantly different from the fit indices of the single-measurement model $\left(x^{2}=3,289.798, d f=885, \quad\right.$ CMIN $/ \mathrm{df}=3.717$, RMSEA $=0.187$; $C F I=0.451)$ compared to the eight-factor confirmatory factor analysis $(\mathrm{CFA})$ $\left(x^{2}=813.668, d f=569, \mathrm{CMIN} / \mathrm{df}=1.42, \mathrm{RMSEA}=0.049, \mathrm{CFI}=0.913, \mathrm{GFI}=0.909, \mathrm{TLI}=0.913\right.$, PCLOSE $=1.00$ ). Thereby, we conclude that the effects of CMV in this study are minimal (Podsakoff et al., 2003).

4.4 Results of the structural equation modelling 
We performed SEM using AMOS 24. The CFA results for our eight-factor model (specified above) demonstrate adequate fit. We performed bootstrapping (with 5000 re-sampling for mediation analysis) to test hypothesis H1 (Hair et al., 2016). The fit indices of the structural model are: $x^{2}=718.614, d f=428, \mathrm{CMIN} / \mathrm{df}=1.67, \mathrm{RMSEA}=0.048, \mathrm{CFI}=0.910, \mathrm{GFI}=0.908$, TLI=0.912, PCLOSE=0.99, also representing adequacy (Hair et al., 2016). Table IV.a contains the results of direct, indirect and total effects of the mediation analysis. These results show that CA mediates the relationship between proactiveness $(h l a)$, innovativeness $(h l b)$ and risk-taking (hlc) and firm performance (total effects: $\beta=0.363, \mathrm{p}=0.028 ; \beta=0.447, \mathrm{p}=0.038$; and $\beta=0.201$, $\mathrm{p}=0.043$, respectively). CA does not mediate the relationships between autonomy ( $h 1 d)$ and competitive aggressiveness (hle) and firm performance (total effects: $\beta=0.030, \mathrm{p}=0.357$ and $\beta=0.041, p=0.755$, respectively). $\mathrm{H} 1$ is partly supported.

[Insert Table IV.a about here]

We performed interaction moderation analysis to test hypotheses $\mathrm{H} 2$ and $\mathrm{H} 3$ (Hair et al., 2016). We developed two moderating models. Table IV.b highlights the moderation results. In the first model, we investigated the moderating effect of SKM capability on the relationships between EO dimensions and CA (H2). The fit indices of the model are: $x^{2}=844.201, d f=492$, $\mathrm{CMIN} / \mathrm{df}=1.71, \mathrm{RMSEA}=0.049, \mathrm{CFI}=0.902, \mathrm{GFI}=0.901, \mathrm{TLI}=0.907, \mathrm{PCLOSE}=0.99$. These statistics indicate appropriate model fit (Hair et al., 2016). The results show that SKM capability moderates the relationships between proactiveness $(\beta=0.321, \mathrm{p}=0.000 ; h 2 a)$, innovativeness $(\beta=0.366, \mathrm{p}=0.000 ; h 2 b)$, risk-taking $(\beta=0.203, \mathrm{p}=0.043 ; h 2 c)$ and CA. SKM capability does not moderate the relationships between autonomy $(\beta=0.088, \mathrm{p}=0.159 ; h 2 d)$, competitive aggressiveness $(\beta=0.071, \mathrm{p}=0.349 ; h 2 e)$, and CA. H2 is partly supported. In the second model, we investigated the moderating effect of SKM capability on the relationships between EO 
dimensions and firm performance (H3). The fit indices indicate appropriate model fit: $x^{2}=$ 965.358, $d f=488, \mathrm{CMIN} / \mathrm{df}=1.97, \mathrm{RMSEA}=0.048, \mathrm{CFI}=0.900, \mathrm{GFI}=0.906, \mathrm{TLI}=0.911$, PCLOSE $=0.99 . S K M$ capability moderates the relationships between proactiveness $(\beta=0.372$, $\mathrm{p}=0.000 ; h 3 a)$, innovativeness $(\beta=0.448, \mathrm{p}=0.000 ; h 3 b)$, risk-taking $(\beta=0.174, \mathrm{p}=0.019 ; h 3 c)$ and firm performance. However, SKM does not moderate the relationship between autonomy $(\beta=0.078, \mathrm{p}=0.375 ; h 3 d)$, competitive aggressiveness $(\beta=0.059, \mathrm{p}=0.451 ; h 3 e)$ and firm performance. H3 is partly supported. Figures 1 to 6 represent the moderating graphs.

$$
\text { [Insert Table IV.b about here] }
$$

[Insert Figures 1 to 6 about here]

Regarding our control variables, the results indicate that firm age, size, munificence, and the number of family member ownership have no significant impact on performance $(\beta=0.026$, $\mathrm{p}=0.238 ; \quad \beta=0.057, \mathrm{p}=0.361 ; \quad \beta=0.021, \quad \mathrm{p}=0.718, \quad$ and $\quad \beta=0.011, \quad \mathrm{p}=0.956$ respectively). Environmental dynamism positively affects firm performance $(\beta=0.021, \mathrm{p}=0.033)$.

\subsection{Endogeneity analysis}

We followed Yin et al. (2020) to examine the possible presence of endogeneity. First, to reduce observation error caused by missing variables, we added innovation speed as a new control variable because innovation speed is an alternative determinant of knowledge-intensive firms' success (Inkinen, 2016). Table V contains the results. After including innovation speed as a control variable in our models, we found that innovativeness, proactiveness, and risk-taking positively impact CA and firm performance; and SKM capability positively moderates these relationships. Second, we performed a Heckman second-stage test to examine for self-selection bias. Table VI shows that the Inverse Mills ratio coefficients lack statistical significance in all second-stage regressions. Hence, the results indicate the absence of self-selection bias (Yin et al., 
2020). Third, we operationalized the family firm owner's human capital as an instrumental variable to further examine endogeneity. Table VII contains the results. The results are consistent in all cases. In addition, Hausman test results provide the confidence that endogeneity is not a challenge to this research (Semadeni et al., 2014).

[Insert Tables V, VI and VII about here]

\subsection{Deep-learning artificial intelligence analysis}

DL-AI is defined as "a massively parallel distributed processor made up of simple processing units, which have a neural propensity for strong experimental knowledge and making it available for use" (Haykin, 2001, p. 2). It is analogous to the human brain because the network created to the program obtains knowledge via a learning procedure, all while comparing against known values contained in the original data. As the program learns, it assigns 'synaptic weights' to learn what knowledge to retain for future use (Leong et al., 2019). Because the program searches for and attempts to learn hidden layers between an input layer (akin to independent variables) and an output layer (akin to a dependent variable), it can capture non-linear relationships between the predictors and criteria variables in ways that SEM or multiple regression analysis simply cannot achieve (Sim et al., 2014). For instance, SEM can result in non-significant relationships due to exogenous and endogenous variables, leading hypotheses to be incorrectly unsupported. Moreover, as organizational phenomena are coupled with complex operations, reductionist bivariate analyses such as regression and SEM omit essential information and determinants of performance or treat them in isolation (Hughes et al., 2019). Hence, DL-AI analysis offers additional in-depth scrutiny of our theoretical model.

DL-AI application does not require the fulfilment of multivariate assumptions, outliers, or sample size conditions (Hew et al., 2019). It relies instead on mathematical models in a 
similar pattern to 'neuron nodes ${ }^{1}$ ' in the brain. The process distributes the neuron nodes into the input, hidden, and output layers of a neural network (Munim et al., 2019). The program learns through an iterative training process and creates and stores knowledge as 'synaptic weights'. The simplest artificial intelligence model has the architecture of input neuron nodes at the bottom layer and the output neuron node at the top layer (analogous to a linear relationship) (Sim et al., 2014). DL-AI incorporates hidden layers (usually two) between the input and output neuron nodes and establishes a non-linear model (Munim et al., 2019), providing a more thorough and complex test of a theoretical model. Hew et al. (2019) note that DL-AI "adjusts the synaptic weights [with each iteration, and]... the bias or error between the actual output and the desired output is propagated in a backward direction, and such process is repeated many times until a minimum bias is achieved" (p. 315). In turn, with each iteration, we can have greater confidence in predicting the outcome and greater clarity on whether an effect is non-linear. SEM models are limited by design; DL-AI resolves this problem.

We used the following equation. Each layer of neuron node receives inputs from the previous layer and the weighted linear combination to estimate the inputs to each neuron node; that is, the total of the inputs $x_{i}$ multiplied by their respective weights $w_{j i}$ as shown in equation (1).

$$
Z_{j}(\bar{X}, \bar{W})=\sum_{i=1}^{n} X_{i} W_{i j}
$$

We adopted the multi-layer perceptron-based feed-forward-back-propagation algorithm because it increases the program's learning and provides for a more thorough test of our

\footnotetext{
1 The input neuron nodes are analogous to exogenous variables, the hidden neuron nodes are created by the intelligence, and the output neuron nodes are analogous to endogenous variables (Munim et al., 2019).
} 
theoretical model. This algorithm refers to the "forward propagation of the input signals [to the output] while the errors are propagated in backward directions [to refine its learning and improve subsequent tests]" (Sim et al., 2014, p. 578). In this process, the neuron nodes of hidden layers learn to present the input neuron nodes effectively and to predict best the output neuron node (Munim et al., 2019). The algorithm employs supervised learning, and the predicted results are compared against known values of the target variables. This process helps the model minimize error (which cannot be achieved in regression analysis) as the DL-AI learns through the learning process (Sim et al., 2014). DL-AI, therefore, produces deeper learning allowing for a thorough test of a proposed model and in a way that overcomes concerns about exogenous and endogenous variables in SEM. We used the sigmoid function to activate both input and hidden layers and let the algorithm automatically generate hidden neuron nodes (Sim et al., 2014). This function generates values approaching $1,0.5$, and very close to zero for large positive numbers, zero, and large negative numbers, respectively. It also permits transition between neuron nodes with low and high output (Hew et al., 2019). The output neuron node is dependent on the activation process of input neuron nodes and their respective weights.

We designed four feed-forward-back-propagation multi-layer perceptrons with twohidden-layer DL-AI architectures using SPSS. Figures 7 to 10 represent the DL-AI models. In Model A, EO's dimensions were the input neuron nodes, and CA was the output neuron node. In Model B, we kept the same input neuron nodes (and included CA as input), with firm performance becoming the output neuron node. In Model $\mathrm{C}$, the interacting variables of EO dimensions and SKM capability were created and used as input neuron nodes to predict CA (the output neuron node). In Model D, we kept the same interacting variables as input neuron nodes (and included CA as input) and changed the output neuron node to firm performance. To avert 
over-fitting problems and achieve consistency, we performed a ten-fold cross-validation procedure in which 90 percent of the data were used for training, and 10 percent were used for testing purposes (Tan et al., 2014). Table VIII reports the high level of predictive accuracy for each of the four DL-AI models. Predictive accuracy is measured by the root mean square error value (RMSE). A lower RMSE value $(\leq 1)$ indicates a better learning quality within DL-AI models. A higher $R^{2}$ value signifies a better prediction level for each DL-AI model (Lee et al., 2020). Our results suggest that all four models adequately predict the output neuron node: $53.59 \%, 58.16 \%, 64.37 \%$ and $66.42 \%$ for Models A, B, C and D, respectively. We also performed sensitivity analyses to rank input neuron nodes based on normalized importance (Lee et al., 2020). Tables IX.a and IX.b highlight the results of these sensitivity analyses.

[Insert Table VIII, IX.a and IX.b about here]

[Insert Figure 7 to 10 about here]

The sensitivity analysis results show that proactiveness (100\%) achieves the highest normalized importance among the EO dimensions in Models A and B; the least importance is achieved by competitive aggressiveness (19.2\% and $7.43 \%$, respectively). Models C and D (contingency models) highlight that the interactive effect of innovativeness and SKM capability achieves the highest normalized importance (100\%). The least important is presented by the interaction effects of autonomy and SKM capability $(22.5 \%$ and $6.4 \%$ in Models C and D, respectively).

\subsection{Post-hoc analysis}

We perform multi-group analysis to identify whether the percentage of family ownership (indicating greater levels of family control; Scholes et al., 2021) might influence the main 
results. We split the sample into two groups based on capital ownership: moderate-level family ownership (50\%-75\% share capital owned by family members; $\mathrm{n}=101)$ and high-level family ownership (76\%-100\% share capital owned by family members; $n=167)$. The ANOVA results highlight that the mean values of innovativeness, proactiveness, risk-taking, SKM capability, CA and firm performance vary statistically significantly between moderate and high-level of family ownership. For detailed results, please refer to the online supplementary materials.

Our results highlight that for a moderate level of family ownership, CA mediates the relationship between innovativeness, proactiveness and risk-taking and firm performance (total effects: $\beta=0.203, p=0.016 ; \beta=0.253, p=0.019$; and $\beta=0.339, p=0.007$, respectively). For a highlevel of family ownership, CA mediates the relationship between innovativeness (total effects: $\beta=0.157, p=0.039)$ and firm performance only. However, CA mediates the relationship between proactiveness and firm performance at the $10 \%$ confidence level (total effects: $\beta=0.071$, $\mathrm{p}=0.076$ ). CA does not mediate the relationship between autonomy, competitive aggressiveness, and firm performance in both models.

Moderation analysis for the moderate level of family ownership. The results of the first moderating model show that SKM capability moderates the relationships between innovativeness $(\beta=0.237, p=0.008)$, risk-taking $(\beta=0.381, p=0.024)$ and $C A ;$ but does not moderate the relationship between proactiveness $(\beta=0.122, \mathrm{p}=0.072$; significant at $10 \%$ confidence level, however), autonomy $(\beta=0.039, \mathrm{p}=0.217)$, competitive aggressiveness $(\beta=0.051, \mathrm{p}=0.486)$ and CA. In the second moderating model, the results show that SKM capability moderates the relationships between innovativeness $(\beta=0.279, \mathrm{p}=0.017)$, risk-taking $(\beta=0.398, \mathrm{p}=0.024)$ and firm performance, but does not moderate the relationship between autonomy $(\beta=0.039, p=0.319)$, 
proactiveness $(\beta=0.171, \mathrm{p}=0.084$; significant at $10 \%$ confidence level), competitive aggressiveness $(\beta=0.016, \mathrm{p}=0.429)$ and firm performance.

Moderation analysis for the high level of family ownership. The results show that SKM capability moderates the relationships between innovativeness $(\beta=0.179, \mathrm{p}=0.026)$, proactiveness $(\beta=0.181, p=0.013)$ and $C A ;$ but does not moderate the relationship between risk-taking ( $\beta=0.068, p=0.632)$, autonomy $(\beta=0.027, p=0.314)$, competitive aggressiveness $(\beta=0.075$, $\mathrm{p}=0.928$ ) and CA. Furthermore, in the second model, SKM capability moderates the relationships between innovativeness $(\beta=0.156, p=0.017)$, proactiveness $(\beta=0.089, p=0.041)$ and firm performance, but does not moderate the relationship between autonomy $(\beta=0.032, p=0.277)$, risk-taking ( $\beta=0.079, \mathrm{p}=0.083$; significant at the $10 \%$ confidence level, however), competitive aggressiveness $(\beta=0.068, \mathrm{p}=0.529)$ and firm performance.

\section{Discussion and contribution}

\subsection{Observed relationships in SEM and DL-AI assessments}

Our primary objective in the study is to probe EO and CA and EO and performance relationships among family firms to evaluate whether CA explains the relationship between EO dimensions and family performance, and whether the magnate of EO's effects strengthens with SKM capability. We use a contingency-based resource orchestration explanation to predict when family firms can benefit from EO and how. Our theoretical narrative and empirical findings provide building blocks for a knowledge-based theory of the family firm. We first discuss our findings, and put forward our theoretical contributions in the following sub-section.

To leverage knowledge resources and to capitalize the most on EO, family firms require a sufficient SKM capability as the mechanism that orchestrates resources to leverage behaviour and outcomes associated with EO. We examine the previously speculated but often ambiguous 
relationship surrounding EO in the family business context. We reveal two new boundary conditions for family firms to profit from EO. We argue and evidence that CA originating from EO mediates the relationship between EO and family firm performance. From the vantage point of resource orchestration theory, we theorize the underlying mechanism to reveal how and why family firms operating in knowledge-intensive industries must nurture SKM capability to orchestrate knowledge resources effectively and align this with appropriate EO dimensions to enhance CA and achieve performance. Our empirical results validate our theoretical model but reveal some additional caveats as to how, when, and why the EO and CA, and EO and performance relationships are contingent on SKM capability. We now explain these results and set out how we contribute to the body of knowledge on family business and knowledge management literature.

Previous studies frequently imply a relationship between EO and CA while mapping causal relationships between the EO dimensions and firm performance. We find that the heterogeneities around EO among family firms originate from CA's omission as a mediator (a new and critical boundary condition) between EO dimensions and family firm performance. Our results support hypotheses $1 a, 1 b$, and $1 c$, and family firms should manifest EO through its innovativeness, proactiveness and risk-bearing dimensions. However, we found no evidence concerning autonomy and competitive aggressiveness. These results are consistent in our posthoc analysis between moderate and high levels of family ownership. The performance rewards that accrue from EO are partially conditional then on the extent to which EO creates CA for the family firm and what specific EO dimensions are implemented (well) by the family firm. The DL-AI analysis brings additional nuance to these SEM-derived results. The DL-AI models show that EO's innovativeness, proactiveness, and risk-taking dimensions are the most significant and 
important peripheral components for family firms. These results yield new insights into when, how, and to what extent the family firm derives performance from EO (called for by Covin and Wales, 2019). Our theory and results enable scholars and managers to make better predictions and judgements based on the DL-AI results about EO's utility for emerging economy firms (as called for by Yin et al., 2020) and family businesses (as called for by Hernández-Linares and López-Fernández, 2018).

The effects of autonomy and competitive aggressiveness in the family firms are nonsignificant, and CA does not mediate the autonomy, competitive aggressiveness, and performance relationships either. But, while our SEM results reject hld and hle, however, the DL-AI results hold that autonomy and competitive aggressiveness are still necessary EO dimensions among family firms given the normalized importance highlighted in models A and B in the sensitivity analysis (see Table IX.a). The DL-AI analysis then reveals that we should not discount the usefulness of autonomy and competitive aggressiveness for family firms. Autonomy is a process that attempts to bring forth a business concept and carry it through to completion (Lumpkin and Dess, 1996). However, McKenny et al. (2018) argue that autonomy serves as a precondition to innovativeness, proactiveness, and risk-taking. Zellweger and Sieger (2012) opine that family firms limit autonomy by involving more personnel in the decision-making process, albeit that involvement is often constrained to family members (Hughes et al., 2018a). Our results contrast with that of Nordqvist et al. (2008) and Garcés-Galdeano et al. (2016). These authors claim autonomy is important for family firms. However, autonomy can clash with the tendency of families to protect their decision rights in the first instance. Regarding competitive aggressiveness, family firms are generally concerned about their long-term reputation and are careful to express a combative posture (Dyer Jr and Whetten, 2006). Our 
results support Nordqvist et al.'s (2008) claim that family firms tend to limit their competitive aggressiveness. Martin and Lumpkin (2003) hold that family firms prefer to preserve the firm's reputation than directly challenge a competitor for market share. Indeed, competitive aggressiveness typically decreases from one generation of a family business to another (Zellweger and Sieger, 2012). In some cases (e.g., Kreiser et al., 2013; Richard et al., 2004; Swierczek and Ha, 2003), competitive aggressiveness and autonomy are considered as parts of the other three dimensions of EO. Therefore, the conceptualization of EO, emphasizing and deemphasizing its various dimensions, must be adjusted more based on a firm's context than traditionally thought.

The SEM results show that SKM capability plays a pivotal role in enhancing CA and firm performance. Firms nurture SKM capability to optimally utilize knowledge resources, reconfigure and execute $\mathrm{KM}$ strategies, embrace a knowledge-based culture that promotes knowledge sharing, and enhance CA (Inkinen, 2016). Merely having EO is not a long-term recipe for family business success (Hernández-Linares and López-Fernández, 2018), and the relationship between EO and performance is dependent on the knowledge management process (Patel and Fiet, 2011; Hughes et al., 2007). However, the form and function of that dependency have escaped careful scrutiny. We theorize and evidence that success is more evident when EO and CA and EO and performance relationships are supported by a sufficient SKM capability in the family firm. EO's manifestation requires leveraging knowledge resources through capabilities to integrate and coordinate the dimensions of EO to provide value to the customer over time (building on McKenny et al., 2018). We argue that an SKM capability dynamically manages, deploys, and utilizes resources to mobilize EO in family firms effectively. SKM capability 
structures, bundles, and leverages knowledge resources to enhance CA and firm performance. Our SEM model legitimizes this thesis.

Interestingly, the DL-AI models C and D extend the SEM results and hold that the interactive effects of innovativeness and SKM capability achieved the highest importance in enhancing CA and firm performance in our sample (see Figure 9 and 10). For these Malaysian family firms in knowledge-intensive industries, transforming their innovative entrepreneurial efforts into wealth creation and CA requires applying knowledge prudently through SKM capability to ensure intelligent entrepreneurial strategic actions. The incorporation of DL-AI along with conventional SEM analysis and our assertions enrich prior findings where SKM capability is reported to influence the relationship between intangible knowledge (e.g., intellectual capital) and performance outcomes (e.g., innovation) (Wang and Chen, 2013; Inkinen et al., 2015; Cabrilo and Dahms, 2018). Effective knowledge management capability is essential to efficiently manage and leverage knowledge resources and transform the organization into a knowledge-based institution capable of capitalizing on EO dimensions. The SKM capability improves CA and firm performance from experimenting and bringing to the fore stateof-the-art technologies, being an innovator and developing new product/service, and proactively leading change in the industry.

Ultimately, however, an SKM capability matters only with specific EO dimensions (innovativeness, proactiveness, and risk-taking), reaffirmed by the SEM and DL-AI analyses. These results are also consistent in the post-hoc moderation analysis between moderate and high levels of family ownership among firms. EO and SKM capability's combined effects will help family firms achieve CA (e.g., price/cost leadership, higher quality and customization in products/service offerings, and adequate time-to-market for products/services) and complement 
overall firm performance. We set two new boundary conditions: for family firms to prioritize CA originating from $\mathrm{EO}$ as the mediator between $\mathrm{EO}$ and firm performance, and the need to nurture a sufficient SKM capability to manage and orchestrate the flow of knowledge resources to augment EO-driven activities to enhance $\mathrm{CA}$ and firm performance.

Finally, our study offers some additional insight into the measurement debate in EO literature (e.g., Covin and Wales, 2012). We show that not all dimensions of EO are equally valuable, suggesting the usefulness of carefully considering the conceptualization of EO. The classic unidimensional model assumes that risk-taking, innovativeness, and proactiveness are equally important and necessary. The five-dimension model foresees the independent effects of these three and competitive aggressiveness and autonomy on firm performance (Hughes and Morgan, 2007). For the Malaysian family firms in our sample, we find clear evidence across the totality of our results that each dimension of EO does not have equal importance or even any bearing on firm performance, accounting for both CA and SKM capability. These mixed results serve further examination in future studies. We suggest scholars consider using configuration analysis to deduce when and which dimensions of EO are more or less critical to a dependent variable of interest (Hughes et al., 2018a).

\subsection{Theoretical contributions}

Our study contributes to the family business and knowledge management literatures by laying essential foundation blocks for a knowledge-based theory of the family.

First, we contribute to the theoretical advancement of EO among family firms (see Calabrò et al., 2020; Hernández-Linares and López-Fernández, 2018; Hughes et al., 2018b) and knowledge management capability (Martinez-Conesa et al., 2017; Cabrilo and Dahms, 2018). Hernández-Linares and López-Fernández (2018), McKenny et al. (2018), Covin and Wales 
(2019), Wales et al. (2020), and Yin et al. (2020) call for a nuanced examination of EO dimensions in different contexts, and specifically with strategic capabilities as contingencies (Calabrò et al., 2020). We relax the conceptualization of EO to configure its dimensions with SKM capability. CA originating from proactiveness, innovativeness, and risk-taking represents a new boundary condition for the EO-performance relationship among family firms.

Second, these effects are more potent with a strong SKM capability. SKM capability provides a powerful contingency to harvest and utilize knowledge resources efficaciously to incubate CA and financial performance from EO-driven efforts among family firms. Hence, our findings reveal the greater predictive accuracy afforded to EO-performance relationships when applying the lens of resource orchestration theory (Sirmon et al., 2011). We also offer an advancement to resource orchestration theory itself by demonstrating the need to consider the firm's strategic posture in understating how the orchestration of resources generates CA and firm performance. To date, this is oddly absent in this theory and has meant that scholars drive attention to the organization of resources without consideration of strategic intent.

Third, unlike prior studies that focus on knowledge accumulation or transformation processes from one generation to another (Chirico, 2008), our contribution extends the conceptualization of an effective knowledge management capability. Family firms operating in a knowledge-intensive industry will thrive depending on how well they utilize the knowledge and align this with EO-driven efforts. In this emerging knowledge-based view of the family firm, we argue that the EO-performance relationship among family firms is knowledge capabilitydependent. However, conversely, EO provides a new construct to understand the relative usefulness of a family firm's knowledge management capability. In the knowledge-based theory of the firm, the (family) firm originates as a repository of knowledge. In principle, it is the 
effective use of that knowledge repository that is essential to creating wealth. However, while capability views of knowledge management explain the efficiency and, to some extent, the effectiveness of a family firm in using knowledge to create a degree of wealth, it struggles to predict the form of that wealth creation without accounting for what sets the motive and direction for its use. As a strategic posture manifested by innovativeness, proactiveness, and risk-taking, EO provides that missing strategic intent. However, we concurrently show that the relationship between EO and SKM is symbiotic. High levels of EO and SKM augment family firm performance and competitive advantage as a precondition to firm performance.

In addition to the main results, our post-hoc analyses re-evaluated our hypotheses against medium and high levels of family ownership. Our results are consistent across medium and high levels of family ownership, providing confidence that family-specific dynamics and (dis)advantages do not deteriorate the utility of EO, the criticality of $\mathrm{CA}$ in mediating its relationship with firm performance, or the moderating effect of SKM. However, these results reinforce that not all dimensions of EO are relevant to the family firm's performance. Clearly, the variety of mechanisms underlying family ownership deserves further attention and more nuanced analysis in future research.

Finally, and methodologically, we combine linear and non-linear statistical analyses, as DL-AI to further enrich our understanding of organizational phenomena (Sim et al., 2014). Consequently, we contribute new knowledge on how scholars can deploy the DL-AI tool to increase their findings' richness and robustness. For instance, our reductionist bivariate analysis using SEM rejects certain expectations surrounding EO, SKM capability, CA and family firm performance. However, DL-AI prioritizes the dimensions of EO, SKM capability, and CA based on normalized importance and offers more nuanced insights. We provide family business and 
knowledge management scholars with a template to leverage DL-AI for sophisticated analyses of family firm outcomes. In the future, DL-AI could be used as a parallel statistical approach to generalize the findings from inferred patterns both in the knowledge management and family business literature.

\subsection{Implications for family business leaders}

First, family firms should urgently build SKM capability as an essential device to increase the strength of the effects an investment in EO dimensions can have on CA and firm performance. To do so, family business leaders must invest in developing routines and procedures for generating, assessing, assimilating, and sharing knowledge across the firm. Without it, the family firm will not materialize the benefits hoped for and anticipated by investment in EO dimensions. To overcome some of these gaps in the immediate term, family business leaders may choose to participate in various government and external party initiatives such as a sophisticated training program centred on better handling and managing knowledge and life-long learning. Proactive participation at international conferences, trade fairs, and global Expo are further initiatives to accumulate information. The purpose of such actions is to engage in activities that ultimately call on the family firm to develop routines for a strategic knowledge management capability.

Malaysian family firms operate in a resource-scarce economy (Falahat et al., 2018). Accumulating information will enable more productive innovation. However, as we show, an SKM capability will enhance the extent to which entrepreneurial endeavours generate competitive advantage and firm performance. At the same time, family firms should evaluate their existing knowledge resources and prudently process them through SKM capability to reap optimal benefits. 
The family firm's manifestation of EO should be well-understood before orchestrating knowledge resources. This means prioritizing innovativeness, proactiveness and risk-taking over autonomy and competitive aggressiveness. Suppose an opportunity identified through EO-driven effort exceeds a firm's ability to realize it. In that case, the chances of gaining maximum benefit from the opportunity and securing CA will be lower. Therefore, the need for continuous nurturing of SKM capability is crucial to utilize knowledge to effectuate CA from new opportunities and achieve superior performance. However, family business leaders should also re-evaluate their key performance indicators because it is the extent to which they realize CA that first defines (and explains) whether the family firm will accrue firm performance from investing in EO and its dimensions. Family business leaders must redouble their efforts to realize potential competitive advantage(s) yielded by EO to ultimately secure performance returns.

\section{Limitations and future research}

Like most empirical studies, our study contains some limitations that can inform future research. First, we collected data from one country. Our results might not reflect the same conditions in different economic settings and exhibit differences when applied to different contexts. Replicating our theory in other economies would be beneficial. Second, our sample represents that these firms are small and young. The knowledge management process is reasonably different in large and established entrepreneurial firms. In some cases, those large firms might not suffer from the country's inefficiencies. Therefore, more nuance examinations are needed to fully understand the knowledge management process in multiple industries under different economic contexts. Culture can also shape entrepreneurial behaviour. Thus, future researchers must consider cultural effects, especially when treating autonomy and competitive aggressiveness. A configurational approach could be adopted to architect comparative models using EO, 
knowledge management process, and performance to contribute to targeted theory development and unpack new avenues for family firm practice.

\section{Conclusions}

Our primary objective with this study was to advance the knowledge of EO, SKM capability, and CA to complement family firm performance. We set a new boundary condition to address the heterogeneities surrounding the EO-performance relationship in family firms. Furthermore, we combined linear and non-linear statistical approaches to understand entrepreneurial behaviour and organizational capability better. Acknowledging the critical boundary condition set by CA is paramount to understand the EO-performance relationship, and merely having EO or SKM capability will not deliver desired outcomes for family firms. The success of family firms will derive from the impeccable alignment of EO dimensions with SKM capability.

\section{References}

Akhtar, C.S., Ismail, K., Hussain, J. and Umair-ur-Rehman, M. (2015), "Investigating the moderating effect of family on the relationship between entrepreneurial orientation and success of enterprise: case of Pakistani manufacturing SMEs", International Journal of Entrepreneurship and Small Business, Vol. 26 No. 2, pp. 233-47.

Armstrong, J.S. and Overton, T.S. (1977), "Estimating nonresponse bias in mail surveys", Journal of Marketing Research, Vol. 14 No. 3, pp. 396-402.

Arzubiaga, U., Maseda, A. and Iturralde, T. (2019), "Entrepreneurial orientation in family firms: New drivers and the moderating role of the strategic involvement of the board", Australian Journal of Management, Vol. 44 No. 1, pp. 128-52.

Arzubiaga, U., Kotlar, J., De Massis, A., Maseda, A. and Iturralde, T. (2018), "Entrepreneurial orientation and innovation in family SMEs: Unveiling the (actual) impact of the Board of Directors", Journal of Business Venturing, Vol. 33 No. 4, pp. 455-69.

Atuahene-Gima, K. and Ko, A. (2001), "An empirical investigation of the effect of market orientation and entrepreneurship orientation alignment on product innovation", Organization Science Vol. 12 No. 1, pp. 54-74.

Bauweraerts, J. and Colot, O. (2017), "Exploring nonlinear effects of family involvement in the board on entrepreneurial orientation", Journal of Business Research, Vol. 70 No. January, pp. 185-92. 
Boling, J.R., Pieper, T.M. and Covin, J.G. (2016), "CEO tenure and entrepreneurial orientation within family and nonfamily firms", Entrepreneurship Theory and Practice, Vol. 40 No. 4, pp. 891-913.

Boso, N., Story, V.M. and Cadogan, J.W. (2013), "Entrepreneurial orientation, market orientation, network ties, and performance: Study of entrepreneurial firms in a developing economy", Journal of Business Venturing, Vol. 28 No. 6, pp. 708-27.

Boumarafi, B. and Jabnoun, N. (2008), "Knowledge management and performance in UAE business organizations", Knowledge Management Research and Practice, Vol. 6 No. 3, pp. 233-38.

Buccieri, D., Javalgi, R.G. and Cavusgil, E. (2019), "International new venture performance: Role of international entrepreneurial culture, ambidextrous innovation, and dynamic marketing capabilities", International Business Review, No. 101639.

Burgelman, R.A. (1983), "A process model of internal corporate venturing in the diversified major firm", Administrative Science Quarterly, Vol. 28, pp. 223-44.

Calabrò, A., Santulli, R., Torchia, M. and Gallucci, C. (2020), "Entrepreneurial Orientation and Family Firm Performance: The Moderating Role of TMT Identity-Based and KnowledgeBased Faultlines", Entrepreneurship Theory and Practice, pp. 1042258720973997.

Cabrilo, S. and Dahms, S. (2018), "How strategic knowledge management drives intellectual capital to superior innovation and market performance", Journal of Knowledge Management, Vol. 22 No. 3, pp. 621-48.

Campbell, J.M. and Park, J. (2016), "Internal and external resources of competitive advantage for small business success: validation across family ownership", International Journal of Entrepreneurship and Small Business, Vol. 27 No. 4, pp. 505-24.

Casillas, J.C., Moreno, A.M. and Barbero, J.L. (2011), "Entrepreneurial orientation of family firms: Family and environmental dimensions", Journal of Family Business Strategy, Vol. 2 No. 2, pp. 90-100.

Casillas, J.C. and Moreno, A.M. (2010), "The relationship between entrepreneurial orientation and growth: The moderating role of family involvement", Entrepreneurship \& Regional Development, Vol. 22 No. 3-4, pp. 265-91.

Carney, M. (2005), "Corporate governance and competitive advantage in family-controlled firms", Entrepreneurship Theory and Practice, Vol. 29 No. 3, pp. 249-65.

Cerchione, R., Esposito, E. and Spadaro, M.R. (2016), "A literature review on knowledge management in SMEs", Knowledge Management Research \& Practice, Vol. 14 No. 2, pp. 169-77.

Chang, S.J., Van Witteloostuijn, A. and Eden, L. (2010), "From the editors: Common method variance in international business research", Journal of International Business Studies, Vol. 41 No. 2, pp. 178-84.

Chirico, F. (2008), "Knowledge accumulation in family firms: Evidence from four case studies", International Small Business Journal, Vol. 26 No. 4, pp. 433-62.

Chirico, F., Sirmon, D.G., Sciascia, S. and Mazzola, P. (2011), "Resource orchestration in family firms: Investigating how entrepreneurial orientation, generational involvement, and participative strategy affect performance", Strategic Entrepreneurship Journal, Vol. 5 No. 4, pp. 307-26.

Covin, J.G. and Slevin, D.P. (1989), "Strategic management of small firms in hostile and benign environments", Strategic Management Journal, Vol. 10 No. 1, pp. 75-87. 
Covin, J.G. and Wales, W.J. (2012), "The measurement of entrepreneurial orientation", Entrepreneurship Theory and Practice, Vol. 36 No. 4, pp. 677-702.

Covin, J.G. and Wales, W.J. (2019), "Crafting high-impact entrepreneurial orientation research: Some suggested guidelines", Entrepreneurship Theory and Practice, Vol. 43 No. 1, pp. $3-18$.

Cruz, C. and Nordqvist, M. (2012), "Entrepreneurial orientation in family firms: A generational perspective", Small Business Economics, Vol. 38 No. 1, pp. 33-49.

Cruz-González, J., López-Sáez, P., Navas-López, J.E. and Delgado-Verde, M. (2014), "Directions of external knowledge search: investigating their different impact on firm performance in high-technology industries", Journal of Knowledge Management, Vol. 18 No. 5, pp. 847-66.

Detienne, K.B., Detienne, D.H. and Joshi, S.A. (2003), "Neural networks as statistical tools for business researchers", Organizational research methods, Vol. 6 No. 2, pp. 236-65.

Dess, G.G. and Robinson Jr, R.B. (1984), "Measuring organizational performance in the absence of objective measures: the case of the privately-held firm and conglomerate business unit", Strategic Management Journal, Vol. 5 No. 3, pp. 265-73.

Dotsika, F. and Patrick, K. (2013), "Collaborative KM for SMEs: a framework evaluation study", Information Technology \& People, Vol. 26 No. 4, pp. 368-82.

Dyer, W.G. (2006), " Examining the "family effect" on firm performance", Family Business Review, Vol. 19 No. 3, pp. 253-73.

Dyer Jr, W.G. and Whetten, D.A. (2006), "Family firms and social responsibility: Preliminary evidence from the S\&P 500", Entrepreneurship Theory and Practice, Vol. 30 No. 6, pp. 785-802.

Dyer Jr, W.G. and Handler, W. (1994), "Entrepreneurship and family business: Exploring the connections", Entrepreneurship Theory and Practice, Vol. 19 No. 1, pp. 71-83.

Fornell, C. and Larcker, D.F. (1981), "Evaluating structural equation models with unobservable variables and measurement error", Journal of Marketing Research, Vol. 18 No. 1, pp. 3950 .

Falahat, M., Knight, G. and Alon, I. (2018), "Orientations and capabilities of born global firms from emerging markets", International Marketing Review, Vol. 35 No. 6, pp. 936-57.

Garcés-Galdeano, L., Larraza-Kintana, M., García-Olaverri, C. and Makri, M. (2016), "Entrepreneurial orientation in family firms: the moderating role of technological intensity and performance", International Entrepreneurship and Management Journal, Vol. 12 No. 1, pp. 27-45.

Gold, A.H., Malhotra, A. and Segars, A.H. (2001), "Knowledge management: An organizational capabilities perspective", Journal of Management Information Systems, Vol. 18 No. 1, pp. 185-214.

Gómez-Mejía, L.R., Haynes, K.T., Núñez-Nickel, M., Jacobson, K.J. and Moyano-Fuentes, J. (2007), "Socioemotional wealth and business risks in family-controlled firms: Evidence from Spanish olive oil mills", Administrative Science Quarterly, Vol. 52 No. 1, pp. 10637.

Grant, R. (1996), "Toward a knowledge-based theory of the firm.", Strategic Management Journal, Vol. 17 No. 1, pp. 109-22.

Guide, V.D.R. and Ketokivi, M. (2015), "Notes from the Editors: Redefining some methodological criteria for the journal", Journal of Operations Management, Vol. 37 No. 1, pp. $5-8$. 
Hair, J.F., Hult, G.T.M., Ringle, C. and Sarstedt, M. (2016), A primer on partial least squares structural equation modeling (PLS-SEM), Sage Publications, New York.

Haykin, S. (2001), Neural Networks: A Comprehensive Foundation, Prentice Hall, Upper Saddle.

Heide, J.B. and Weiss, A.M. (1995), "Vendor consideration and switching behavior for buyers in high-technology markets", Journal of Marketing, Vol. 59 No. 3, pp. 30-43.

Heisig, P., Adekunle, S.O., Kianto, A., Kemboi, C., Perez-Arrau, G. and Easa, N. (2016), "Knowledge management and business performance: global experts' views on future research needs", Journal of Knowledge Management, Vol. 20 No. 6, pp. 1169-98.

Hernández-Linares, R. and López-Fernández, M.C. (2018), "Entrepreneurial orientation and the family firm: Mapping the field and tracing a path for future research", Family Business Review, Vol. 31 No. 3, pp. 318-51.

Herrero, I. and Hughes, M. (2019), "When family social capital is too much of a good thing", Journal of Family Business Strategy, Vol. 10 No. 3, pp. 100271.

Hew, J.J., Leong, L.Y., Tan, G.W.H., Ooi, K.B. and Lee, V.H. (2019), "The age of mobile social commerce: An Artificial Neural Network analysis on its resistances", Technological Forecasting and Social Change, Vol. 144, pp. 311-24.

Hill, C.W. and Snell, S.A. (1989), "Effects of ownership structure and control on corporate productivity", Academy of Management Journal, Vol. 32 No. 1, pp. 25-46.

Hu, Q. and Hughes, M. (2020), "Radical Innovation in Family Firms: A Systematic Analysis and Research Agenda", International Journal of Entrepreneurial Behavior \& Research, Vol. 26 No. 6, pp. 1199-234.

Hughes, M., Cesinger, B., Cheng, C.F., Schuessler, F. and Kraus, S. (2019), "A configurational analysis of network and knowledge variables explaining Born Globals' and late internationalizing SMEs' international performance", Industrial Marketing Management, Vol. 80 No. 5, pp. 172-87.

Hughes, M., Hughes, P. and Morgan, R.E. (2007), "Exploitative learning and entrepreneurial orientation alignment in emerging young firms: Implications for market and response performance", British Journal of Management, Vol. 18 No. 18, pp. 359-75.

Hughes, M. and Morgan, R.E. (2007), "Deconstructing the relationship between entrepreneurial orientation and business performance at the embryonic stage of firm growth", Industrial Marketing Management, Vol. 36 No. 5, pp. 651-61.

Hughes, M., Martin, S.L., Morgan, R. and Robson, M. (2010), "Realizing Product-Market Advantage in High-Technology International New Ventures: The Mediating Role of Ambidextrous Innovation", Journal of International Marketing, Vol. 18 No. 4, pp. 1-21.

Hughes, M., Morgan, R.E., Ireland, R.D. and Hughes, P. (2014), "Social Capital and Learning from Network Relationships: A Problem of Absorptive Capacity", Strategic Entrepreneurship Journal, Vol. 8 No. 3, pp. 214-33.

Hughes, M., Filser, M., Harms, R., Kraus, S., Chang, M.-L., \& Cheng, C.-F. (2018a). "Family firm configurations for high performance: The role of entrepreneurship and ambidexterity", British Journal of Management, 29(4), 595-612.

Hughes, P., Hodgkinson, I.R., Hughes, M. and Arshad, D. (2018b), "Explaining the entrepreneurial orientation-performance relationship: The intermediate roles of absorptive capacity and improvisation", Asia Pacific Journal of Management, Vol. 35, pp. 1025-53. 
Hughes, M., Hughes, P., Morgan, R. E., Hodgkinson, I. R., \& Lee, Y. (2021). "Strategic Entrepreneurship Behaviour and the Innovation Ambidexterity of Young Technologybased Firms in Incubators", International Small Business Journal, Vol. 39 No. 3, pp.202227.

Inkinen, H. (2016), "Review of empirical research on knowledge management practices and firm performance", Journal of Knowledge Management, Vol. 20 No. 2, pp. 230-57.

Inkinen, H., Kianto, A. and Vanhala, M. (2015), "Knowledge management practices and innovation performance in Finland", Baltic Journal of Management, Vol. 10 No. 4, pp. 432-55.

Jambulingam, T., Kathuria, R. and Doucette, W.R. (2005), "Entrepreneurial orientation as a basis for classification within a service industry: The case of retail pharmacy industry", Journal of Operations Management, Vol. 23 No. 1, pp. 23-42.

Jiménez-Jiménez, D., Sanz-Valle, R. and Perez-Caballero, J.A. (2020), "Entrepreneurial orientation and innovation success in family firms", International Journal of Entrepreneurship and Small Business, Vol. 40 No. 1, pp. 114-27.

Kallmuenzer, A. and Peters, M. (2017), "Exploring entrepreneurial orientation in family firms: the relevance of social embeddedness in competition", International Journal of Entrepreneurship and Small Business, Vol. 30 No. 2, pp. 191-213.

Kallmuenzer, A. and Peters, M. (2018), "Innovativeness and control mechanisms in tourism and hospitality family firms: A comparative study", International Journal of Hospitality Management, Vol. 70, pp. 66-74.

Kallmuenzer, A., Strobl, A. and Peters, M. (2018), "Tweaking the entrepreneurial orientationperformance relationship in family firms: the effect of control mechanisms and familyrelated goals", Review of Managerial Science, Vol. 12 No. 4, pp. 855-83.

Kearney, C., Soleimanof, S. and Wales, W.J. (2018), "Examining facilitative configurations of entrepreneurially oriented growth: An information processing perspective", British Journal of Management, Vol. 29 No. 3, pp. 514-33.

Kirca, A.H. (2011), "The effects of market orientation on subsidiary performance: Empirical evidence from MNCs in Turkey", Journal of World Business, Vol. 46 No. 4, pp. 447-54.

Kreiser, P.M., Marino, L.D., Kuratko, D.F. and Weaver, K.M. (2013), "Disaggregating entrepreneurial orientation: the non-linear impact of innovativeness, proactiveness and risk-taking on SME performance", Small Business Economics, Vol. 40 No. 2, pp. 273-91.

Lee, V.H., Hew, J.J., Leong, L.Y., Tan, G.W.H. and Ooi, K.B. (2020), "Wearable payment: A deep learning-based dual-stage SEM-ANN analysis", Expert systems with Applications.

Leong, L.Y., Hew, T.S., Ooi, K.B., Lee, V.H. and Hew, J.J. (2019), "A hybrid SEM-neural network analysis of social media addiction", Expert systems with Applications, Vol. 133 No. 7, pp. 296-316.

Li, S., Ragu-Nathan, B., Ragu-Nathan, T.S. and Rao, S.S. (2006), "The impact of supply chain management practices on competitive advantage and organizational performance", Omega, Vol. 34 No. 2, pp. 107-24.

Liao, C., Chuang, S.H. and To, P.L. (2011), "How knowledge management mediates the relationship between environment and organizational structure", Journal of Business Research, Vol. 64 No. 7, pp. 728-36.

Lumpkin, G.T., Brigham, K.H. and Moss, T.W. (2010), "Long-term orientation: Implications for the entrepreneurial orientation and performance of family businesses", Entrepreneurship \& Regional Development, Vol. 22 No. 3-4, pp. 241-64. 
Lumpkin, G.T. and Dess, G.G. (1996), "Clarifying the entrepreneurial orientation construct and linking it to performance", Academy of Management Review, Vol. 21 No. 1, pp. 135-72.

Lumpkin, G.T. and Dess, G.G. (2001), "Linking two dimensions of entrepreneurial orientation to firm performance: The moderating role of environment and industry life cycle", Journal of Business Venturing, Vol. 15 No. 5, pp. 429-51.

MacMillan, I.C. and Day, D.L. (1987), "Corporate ventures into industrial markets: Dynamics of aggressive entry", Journal of Business Venturing, Vol. 2 No. 1, pp. 29-39.

Madison, K., Runyan, R.C. and Swinney, J.L. (2014), "Strategic posture and performance: Revealing differences between family and nonfamily firms", Journal of Family Business Strategy, Vol. 5 No. 3, pp. 239-51.

March, J.G. (2006), "Rationality, foolishness, and adaptive intelligence", Strategic Management Journal, Vol. 27 No. 3, pp. 201-14.

Martin, L. and Lumpkin, T. (2003), "From EO to "family orientation'?: Generational differences in the management of family businesses", in 22nd Babson College entrepreneurship research conference, Babson College, Massachusetts.

Martinez-Conesa, I., Soto-Acosta, P. and Carayannis, E.G. (2017), "On the path towards open innovation: assessing the role of knowledge management capability and environmental dynamism in SMEs", Journal of Knowledge Management, Vol. 21 No. 3, pp. 553-70.

MASTIC. (2019), "National Survey of Research and Development (R\&D) in Malaysia 2019", in Gross Expenditure on Research and Development, Federal Government Administrative Centre, Putrajaya, Malaysia.

McKenny, A.F., Short, J.C., Ketchen Jr, D.J., Payne, G.T. and Moss, T.W. (2018), "Strategic entrepreneurial orientation: Configurations, performance, and the effects of industry and time", Strategic Entrepreneurship Journal, Vol. 12 No. 4, pp. 504-21.

MEDAC. (2018), "Ministry of Entrepreneur Development and Cooperatives' National Entrepreneurs Directory", available at: dun.medac.gov.my/.

Menguc, B. and Auh, S. (2008), "The asymmetric moderating role of market orientation on the ambidexterity-firm performance relationship for prospectors and defenders", Industrial Marketing Management Vol. 37, pp. 455-70.

Miller, D. and Friesen, P.H. (1982), "Innovation in conservative and entrepreneurial firms: Two models of strategic momentum", Strategic Management Journal, Vol. 3 No. 1, pp. 1-25.

Morris, M.H., Webb, J.W. and Franklin, R.J. (2011), "Understanding the manifestation of entrepreneurial orientation in the nonprofit context", Entrepreneurship Theory and Practice, Vol. 35 No. 5, pp. 947-71.

MOSTI. (2018), "National Survey of Innovation 2018 - Manufacturing and Services Sector in Malaysia", in, Malaysian Science and Technology Information Centre, Putrajaya, Malaysia.

MTE. (2020), "Malaysia Technology Expo 2020", available at: https://mte.org.my/ (accessed 2 July 2020.

Munim, Z.H., Shakil, M.H. and Alon, I. (2019), "Next-day bitcoin price forecast", Journal of Risk and Financial Management, Vol. 12 No. 2, pp. 103-18.

Muñoz-Bullón, F. and Sanchez-Bueno, M.J. (2011), "The impact of family involvement on the R\&D intensity of publicly traded firms", Family Business Review, Vol. 24 No. 1, pp. 6270 . 
Naldi, L., Nordqvist, M., Sjöberg, K. and Wiklund, J. (2007), "Entrepreneurial orientation, risk taking, and performance in family firms", Family Business Review, Vol. 20 No. 1, pp. 3347.

Nordqvist, M., Habbershon, T.G. and Melin, L. (2008), Transgenerational entrepreneurship: Exploring EO in family firms, Entrepreneurship, sustainable growth and performance: Frontiers in European entrepreneurship research, Edward Elgar, Cheltenham, U.K.

Patel, P.C. and Fiet, J.O. (2011), "Knowledge combination and the potential advantages of family firms in searching for opportunities. ", Entrepreneurship Theory and Practice, Vol. 35 No. 6, pp. 1179-97.

Patel, P.C., Kohtamäki, M., Parida, V. and Wincent, J. (2015), "Entrepreneurial orientation-as-experimentation and firm performance: The enabling role of absorptive capacity", Strategic Management Journal, Vol. 36 No. 11, pp. 1739-49.

Pimentel, D., Couto, J.P. and Scholten, M. (2017), "Entrepreneurial orientation in family firms: Looking at a European outermost region ", Journal of Enterprising Culture, Vol. 25 No. 4, pp. 441-460.

Podsakoff, P.M., MacKenzie, S.B., Lee, J.Y. and Podsakoff, N.P. (2003), "Common method biases in behavioral research: a critical review of the literature and recommended remedies", Journal of applied psychology, Vol. 88 No. 5, pp. 879-903.

Powell, T.C. (1992), "Organizational alignment as competitive advantage", Strategic Management Journal, Vol. 13 No. 2, pp. 113-34.

Richard, O.C., Barnett, T., Dwyer, S. and Chadwick, K. (2004), "Cultural diversity in management, firm performance, and the moderating role of entrepreneurial orientation dimensions", Academy of Management Journal, Vol. 47 No. 2, pp. 255-66.

Sanchez-Famoso, V., Iturralde, T. and Maseda, A. (2015), "The influence of family and nonfamily social capital on firm innovation: exploring the role of family ownership", European journal of International Management, Vol. 9 No. 2, pp. 240-62.

Schepers, J., Voordeckers, W., Steijvers, T. and Laveren, E. (2014), "The entrepreneurial orientation-performance relationship in private family firms: the moderating role of socioemotional wealth", Small Business Economics, Vol. 43 No. 1, pp. 39-55.

Schultz, R., Slevin, D.P. and Covin, J.G. (1995), "The strategic management profile: An executive questionnaire", University of Pittsburgh, Pittsburgh.

Scholes, L., Hughes, M., Wright, M., De Massis, A. and Kotlar, J. (2021), "Family Management and Family Guardianship: Governance Effects on Family Firm Innovation Strategy", Journal of Family Business Strategy, (in press).

Semadeni, M., Withers, M.C. and Trevis Certo, S. (2014), "The perils of endogeneity and instrumental variables in strategy research: Understanding through simulations", Strategic Management Journal, Vol. 35 No. 7, pp. 1070-79.

Sharma, P., Chrisman, J.J. and Chua, J.H. (1997), "Strategic management of the family business: Past research and future challenges", Family Business Review, Vol. 10 No. 1, pp. 1-35.

Short, J.C., Payne, G.T., Brigham, K.H., Lumpkin, G.T. and Broberg, J.C. (2009), "Family firms and entrepreneurial orientation in publicly traded firms: A comparative analysis of the S\&P 500", Family Business Review, Vol. 22 No. 1, pp. 9-24.

Sidhu, J.S., Commandeur, H.R. and Volberda, H.W. (2007), "The multifaceted nature of exploration and exploitation: value of supply, demand, and spatial search for innovation", Organization Science, Vol. 18 No. 1, pp. 20-38. 
Sim, J.J., Tan, G.W.H., Wong, J.C., Ooi, K.B. and Hew, T.S. (2014), "Understanding and predicting the motivators of mobile music acceptance-a multi-stage MRA-artificial neural network approach", Telematics and Informatics, Vol. 31 No. 4, pp. 569-84.

Singh, J. and Fleming, L. (2010), "Lone inventors as sources of breakthroughs: Myth or reality?", Management Science, Vol. 56 No. 1, pp. 41-56.

Sirmon, D.G., Hitt, M.A. and Ireland, R.D. (2007), "Managing firm resources in dynamic environments to create value: Looking inside the black box", Academy of Management Review, Vol. 32 No. 1, pp. 273-92.

Sirmon, D.G., Hitt, M.A., Ireland, R.D. and Gilbert, B.A. (2011), "Resource orchestration to create competitive advantage: breadth, depth, and life cycle effects", Journal of Management Vol. 37 No. 5, pp. 1390-412.

Skyrme, D. and Amidon, D. (1997), "The knowledge agenda", Journal of Knowledge Management, Vol. 1 No. 1, pp. 27-37.

Slater, S.F. and Narver, J.C. (1998), "Customer-led and market-oriented: let's not confuse the two", Strategic Management Journal, Vol. 19 No. 10, pp. 1001-06.

Smith, K., Ferrier, W. and Grimm, C. (2001), "King of the hill: Dethroning the industry leader", Academy of Management Executive, Vol. 15, pp. 59-70.

Stenholm, P., Pukkinen, T. and Heinonen, J. (2016), "Firm growth in family businesses-The role of entrepreneurial orientation and the entrepreneurial activity", Journal of Small Business Management, Vol. 54 No. 2, pp. 697-713.

Swierczek, F.W. and Ha, T.T. (2003), "Entrepreneurial orientation, uncertainty avoidance and firm performance: an analysis of Thai and Vietnamese SMEs", The International Journal of Entrepreneurship and Innovation, Vol. 4 No. 1, pp. 46-58.

Tan, G.W.H., Ooi, K.B., Leong, L.Y. and Lin, B. (2014), "Predicting the drivers of behavioral intention to use mobile learning: a hybrid SEM-neural networks approach", Computer in Human Behaviour, Vol. 36 No. 9, pp. 198-213.

Tat, L.W. and Hase, S. (2007), "Knowledge management in the Malaysian aerospace industry", Journal of Knowledge Management, Vol. 11 No. 1, pp. 143-51.

Taylor, A. and Greve, H.R. (2006), "Superman or the fantastic four? Knowledge combination and experience in innovative teams", Academy of Management Journal, Vol. 49 No. 4, pp. 723-40.

Tracey, M., Vonderembse, M.A. and Lim, J.-S. (1999), "Manufacturing technology and strategy formulation: keys to enhancing competitiveness and improving performance", Journal of Operations Management, Vol. 17 No. 4, pp. 411-28.

Turulja, L. and Bajgorić, N. (2018), "Knowledge Acquisition, Knowledge Application, and Innovation Towards the Ability to Adapt to Change", International Journal of Knowledge Management, Vol. 14 No. 2, pp. 1-15.

Uhlaner, L.M., Kellermanns, F.W., Eddleston, K.A. and Hoy, F. (2012), "The entrepreneuring family: A new paradigm for family business research", Small Business Economics, Vol. 38 No. 1 , pp. 1-11.

Venkatraman, N. (1989), "Strategic orientation of business enterprises: The construct, dimensionality, and measurement", Management Science, Vol. 35 No. 1, pp. 942-62.

Wales, W., Gupta, V.K., Marino, L. and Shirokova, G. (2019), "Entrepreneurial orientation: International, global and cross-cultural research", International Small Business Journal, Vol. 37 No. 2, pp. 95-104. 
Wales, W.J., Covin, J.G. and Monsen, E. (2020), "Entrepreneurial Orientation: The Necessity of a Multi-Level Conceptualization", Strategic Entrepreneurship Journal.

Wales, W.J., Gupta, V.K. and Mousa, F.T. (2013a), "Empirical research on entrepreneurial orientation: An assessment and suggestions for future research", International Small Business Journal, Vol. 3 No. 4, pp. 357-83.

Wales, W.J., Patel, P.C., Parida, V. and Kreiser, P.M. (2013b), "Nonlinear effects of entrepreneurial orientation on small firm performance: The moderating role of resource orchestration capabilities", Strategic Entrepreneurship Journal, Vol. 7 No. 2, pp. 93-121.

Wang, D. and Chen, S. (2013), "Does intellectual Capital matter? high-performance work systems and bilateral innovative capabilities", International Journal of Manpower, Vol. 34 No. 8, pp. 861-79.

Wiklund, J. and Shepherd, D.A. (2011), "Where to from here? EO-as-experimentation, failure, and distribution of outcomes", Entrepreneurship Theory and Practice, Vol. 35 No. 5, pp. 925-46.

Winter, S.G. (2003), "Understanding dynamic capabilities", Strategic Management Journal, Vol. 24 No. 10, pp. 991-95.

Yin, M., Hughes, M. and Hu, Q. (2020), "Entrepreneurial orientation and new venture resource acquisition: why context matters", Asia Pacific Journal of Management, (early cite).

Zack, M.H. (1999), "Managing codified knowledge", Sloan management review, Vol. 40 No. 4, pp. 45-58.

Zahra, S.A. (2012), "Organizational learning and entrepreneurship in family firms: Exploring the moderating effect of ownership and cohesion", Small Business Economics, Vol. 38 No. 1, pp. 51-65.

Zahra, S.A., Neubaum, D.O. and Larrañeta, B. (2007), "Knowledge sharing and technological capabilities: The moderating role of family involvement", Journal of Business Research, Vol. 60 No. 10, pp. 1070-79.

Zahra, S.A. and Covin, J. (1995), "Contextual influences on the corporate entrepreneurshipperformance relationship: a longitudinal analysis", Journal of Business Venturing, Vol. 10 No. 1, pp. 43-58.

Zahra, S.A., Hayton, J.C. and Salvato, C. (2004), "Entrepreneurship in family vs. non-family firms: A resource-based analysis of the effect of organizational culture", Entrepreneurship Theory and Practice, Vol. 28 No. 4, pp. 363-81.

Zainol, F.A. (2013), "The antecedents and consequences of entrepreneurial orientation in Malay family firms in Malaysia", International Journal of Entrepreneurship and Small Business, Vol. 18 No. 1, pp. 103-23.

Zellweger, T. and Sieger, P. (2012), "Entrepreneurial orientation in long-lived family firms", Small Business Economics, Vol. 38 No. 1, pp. 67-84. 
Table I. Heterogeneities of EO among family firms

\begin{tabular}{|c|c|c|}
\hline Authors & Context & Outcomes \\
\hline Naldi et al. (2007) & $\begin{array}{l}\text { Sweden: manufacturing, } \\
\text { professional service, } \\
\text { wholesale/retail, and other } \\
\text { services. }\end{array}$ & Risk-taking negatively affects family firm performance. \\
\hline Short et al. (2009) & $\begin{array}{l}\text { S\&P } 500 \text { firms: mining, } \\
\text { manufacturing, transportation, } \\
\text { commodities, finance, insurance, } \\
\text { and real estate. }\end{array}$ & $\begin{array}{l}\text { The family firm possesses a low level of proactiveness } \\
\text { and autonomy. }\end{array}$ \\
\hline $\begin{array}{l}\text { Casillas and Moreno } \\
\text { (2010) }\end{array}$ & $\begin{array}{l}\text { Spain: agriculture, real estate, } \\
\text { and service sector. }\end{array}$ & $\begin{array}{l}\text { Competitive aggressiveness and autonomy exhibit no } \\
\text { relationship with family firm performance. }\end{array}$ \\
\hline Madison et al. (2014) & $\begin{array}{l}\text { USA: Real estate, financial, } \\
\text { medical, barber, jewellery and } \\
\text { restaurant. }\end{array}$ & $\begin{array}{l}\text { Innovativeness, risk-taking, and proactiveness have no } \\
\text { significant effects on family firm performance. }\end{array}$ \\
\hline Schepers et al. (2014) & $\begin{array}{l}\text { Belgium: manufacturing, } \\
\text { construction, wholesale, retail } \\
\text { and services. }\end{array}$ & $\begin{array}{l}\text { The positive effects of proactiveness, risk-taking and } \\
\text { innovativeness decrease when family firms' socio- } \\
\text { economic wealth increases. }\end{array}$ \\
\hline Akhtar et al. (2015) & Pakistan: surgical manufacturing. & $\begin{array}{l}\text { Only proactiveness and autonomy have a significant } \\
\text { impact on family firm success. }\end{array}$ \\
\hline $\begin{array}{l}\text { Campbell and Park } \\
\text { (2016) }\end{array}$ & $\begin{array}{l}\text { USA: retail, wholesale and } \\
\text { financial, administration, trade, } \\
\text { health, food, and recreation. }\end{array}$ & EO enhances family firm performance. \\
\hline $\begin{array}{l}\text { Garcés-Galdeano et } \\
\text { al. (2016) }\end{array}$ & Spain: manufacturing. & $\begin{array}{l}\text { Family firms are less entrepreneurially oriented, and there } \\
\text { is no evidence that a change in the entrepreneurial } \\
\text { orientation causes changes in the performance. }\end{array}$ \\
\hline $\begin{array}{l}\text { Stenholm et al. } \\
\text { (2016) }\end{array}$ & $\begin{array}{l}\text { Finland: food industry, media, } \\
\text { shipbuilding, furnishing and } \\
\text { maintenance. }\end{array}$ & $\begin{array}{l}\text { Innovativeness complements family firm performance; } \\
\text { however, risk-taking does not contribute to the growth of } \\
\text { the firm. }\end{array}$ \\
\hline $\begin{array}{l}\text { Kallmuenzer and } \\
\text { Peters (2017) }\end{array}$ & $\begin{array}{l}\text { Austria: restaurant, hospitality } \\
\text { and construction. }\end{array}$ & $\begin{array}{l}\text { Competitive aggressiveness does not play any significant } \\
\text { role in the family business. }\end{array}$ \\
\hline Pimentel et al. (2017) & Portugal: handcraft. & $\begin{array}{l}\text { The levels of innovativeness and risk-taking are much } \\
\text { lower among family firms. }\end{array}$ \\
\hline $\begin{array}{l}\text { Kallmuenzer and } \\
\text { Peters (2018) }\end{array}$ & $\begin{array}{l}\text { Austria: wholesale, retail, IT, } \\
\text { leisure, logistics, manufacturing } \\
\text { and handcraft. }\end{array}$ & $\begin{array}{l}\text { Risk-taking has a nonsignificant role to play in enhancing } \\
\text { performance. }\end{array}$ \\
\hline $\begin{array}{l}\text { Kallmuenzer et al. } \\
\text { (2018) }\end{array}$ & $\begin{array}{l}\text { Austria: tourism \& hospitality, } \\
\text { handcraft, manufacturing, retail, } \\
\text { wholesale, IT and transport. }\end{array}$ & \begin{tabular}{lllll} 
Risk-taking, & \multicolumn{2}{c}{ innovativeness and } & \multicolumn{2}{c}{ competitive } \\
aggressiveness & have no bearing on family firm \\
performance. & & & &
\end{tabular} \\
\hline $\begin{array}{l}\text { Arzubiaga et al. } \\
\text { (2019) }\end{array}$ & $\begin{array}{l}\text { Spain: automotive, electric, steel, } \\
\text { food, and chemistry }\end{array}$ & $\begin{array}{l}\text { EO enhances the ambidextrous innovation of family } \\
\text { firms. }\end{array}$ \\
\hline Calabrò et al. (2020) & Germany: manufacturing & EO positively enhances return on assets in family firms \\
\hline
\end{tabular}


Table II. Descriptive statistics $(n=268)$

\begin{tabular}{|c|c|c|c|c|c|c|c|c|}
\hline Construct & 1 & 2 & 3 & 4 & 5 & 6 & 7 & 8 \\
\hline (1) Innovativeness & 0.766 & & & & & & & \\
\hline (2) Proactiveness & $0.487 * *$ & 0.711 & & & & & & \\
\hline (3) Risk-taking & $0.269^{* *}$ & $0.283^{* *}$ & 0.719 & & & & & \\
\hline (4) Competitive aggressiveness & $0.182 *$ & $0.124 *$ & $0.330 * *$ & 0.729 & & & & \\
\hline (5) Autonomy & $0.175^{*}$ & $0.233^{* *}$ & $0.137 *$ & $0.198^{* *}$ & 0.723 & & & \\
\hline $\begin{array}{l}\text { (6) Strategic knowledge management } \\
\text { capability }\end{array}$ & $0.508 * *$ & $0.532 * *$ & $0.281 * *$ & $0.176^{*}$ & $0.125^{*}$ & 0.713 & & \\
\hline (7) Competitive advantage & $0.501 * *$ & $0.508 * *$ & $0.386^{* *}$ & $0.183^{*}$ & $0.133 *$ & $0.537 * *$ & 0.712 & \\
\hline (8) Firm performance & $0.557 * *$ & $0.553^{* *}$ & $0.251^{* *}$ & $0.161^{*}$ & $0.131 *$ & $0.549^{* *}$ & $0.616^{* *}$ & 0.748 \\
\hline \multicolumn{9}{|l|}{ Control variables } \\
\hline Firm age & $0.188^{*}$ & $0.204^{* *}$ & 0.034 & 0.044 & $0.144 *$ & $0.301 * *$ & $0.210^{* *}$ & $0.279 * *$ \\
\hline Firm size & $0.147^{*}$ & $0.144 *$ & 0.087 & $0.105^{*}$ & 0.084 & $0.217 * *$ & $0.272 * *$ & $0.263^{* *}$ \\
\hline Dynamism & 0.069 & 0.073 & 0.056 & 0.041 & 0.014 & 0.088 & $0.268 * *$ & $0.126^{*}$ \\
\hline Munificence & 0.036 & 0.066 & 0.018 & 0.039 & 0.036 & 0.066 & $0.161^{*}$ & $0.124 *$ \\
\hline Number of family member ownership & 0.021 & 0.038 & 0.037 & 0.019 & 0.047 & 0.093 & 0.057 & 0.048 \\
\hline Mean score & 21.12 & 13.57 & 13.86 & 13.26 & 13.88 & 22.93 & 69.65 & 27.92 \\
\hline Standard deviation & 2.6 & 1.1 & 1.9 & 1.3 & 1.8 & 3.1 & 7.32 & 3.1 \\
\hline Skewness & -0.338 & -0.877 & 0.484 & -0.595 & -0.211 & 0.601 & -0.131 & 0.116 \\
\hline Kurtosis & 0.544 & 0.454 & -0.642 & 0.717 & -0.496 & 0.781 & 0.309 & 0.011 \\
\hline VIF & 1.88 & 1.57 & 1.71 & 1.44 & 1.19 & 2.11 & 2.18 & 2.47 \\
\hline
\end{tabular}

Note: Diagonal is the square root of the AVE.

*Correlations significant at the 0.05 level

**Correlations significant at the 0.01 level

Table III. Reliability and validity

\begin{tabular}{lcccc}
\hline Construct & $\alpha$ & CR & AVE & MSV \\
\hline (1) Innovativeness & 0.792 & 0.786 & 0.587 & 0.204 \\
(2) Proactiveness & 0.775 & 0.739 & 0.506 & 0.212 \\
(3) Risk-taking & 0.727 & 0.717 & 0.518 & 0.161 \\
(4) Competitive aggressiveness & 0.820 & 0.770 & 0.532 & 0.230 \\
(5) Autonomy & 0.773 & 0.733 & 0.524 & 0.253 \\
(6) Strategic knowledge management & 0.702 & 0.754 & 0.509 & 0.133 \\
capability & & & & \\
(7) Competitive advantage & 0.747 & 0.760 & 0.508 & 0.238 \\
(8) Firm performance & 0.872 & 0.732 & 0.561 & 0.255 \\
\hline
\end{tabular}

Table IV.a Direct, indirect and total effects

\begin{tabular}{|c|c|c|c|c|c|}
\hline \multirow[b]{2}{*}{ Constructs } & \multirow[b]{2}{*}{$\begin{array}{l}\text { Type of } \\
\text { effects }\end{array}$} & \multicolumn{2}{|c|}{ Competitive advantage } & \multicolumn{2}{|c|}{ Firm performance } \\
\hline & & Coefficient & p-value & Coefficient & p-value \\
\hline \multirow{3}{*}{ Proactiveness } & Direct & $0.278 * * *$ & 0.001 & $0.271 * * *$ & 0.001 \\
\hline & Indirect & - & - & $0.108 * *$ & 0.023 \\
\hline & Total & $0.278 * * *$ & 0.001 & $0.363 * *$ & 0.028 \\
\hline \multirow[t]{3}{*}{ Innovativeness } & Direct & $0.363 * * *$ & 0.000 & $0.316^{* * * *}$ & 0.000 \\
\hline & Indirect & - & - & $0.127 * *$ & 0.030 \\
\hline & Total & $0.363 * * *$ & 0.000 & $0.447 * *$ & 0.038 \\
\hline \multirow[t]{3}{*}{ Risk-taking } & Direct & $0.117 * *$ & 0.029 & $0.164 * *$ & 0.033 \\
\hline & Indirect & - & - & $0.062 *$ & 0.078 \\
\hline & Total & $0.117 * *$ & 0.029 & $0.201 * *$ & 0.043 \\
\hline \multirow[t]{3}{*}{ Autonomy } & Direct & 0.011 & 0.152 & 0.027 & 0.298 \\
\hline & Indirect & - & - & 0.008 & 0.236 \\
\hline & Total & 0.011 & 0.152 & 0.030 & 0.357 \\
\hline \multirow[t]{2}{*}{ Competitive } & Direct & 0.040 & 0.257 & 0.032 & 0.455 \\
\hline & Indirect & - & - & 0.070 & 0.646 \\
\hline
\end{tabular}




\begin{tabular}{llcccc} 
aggressiveness & Total & 0.040 & 0.257 & 0.041 & 0.755 \\
Competitive & Direct & - & - & $0.463 * * *$ & 0.000 \\
advantage & Indirect & - & - & - & - \\
& Total & - & - & $0.464 * * *$ & 0.000 \\
\hline
\end{tabular}

Note: Critical ratio greater than 1.96 is significant at $* * p<0.05, * * * p<0.01$

Table IV.b Moderation analyses

\begin{tabular}{lcccc}
\hline Constructs & \multicolumn{2}{c}{ Competitive advantage (model 1) } & \multicolumn{2}{c}{ Firm performance (model 2) } \\
\cline { 2 - 5 } & Coefficient & p-value & Coefficient & p-value \\
\hline Control variables & Yes & Yes & Yes & Yes \\
Proactiveness * SKM Capability & $0.321 * * *$ & 0.000 & $0.372 * * *$ & 0.000 \\
Innovativeness * SKM Capability & $0.366 * * *$ & 0.000 & $0.448 * * *$ & 0.000 \\
Risk-taking * SKM Capability & $0.203 * *$ & 0.043 & $0.174 * *$ & 0.019 \\
Autonomy * SKM Capability & 0.088 & 0.159 & 0.078 & 0.375 \\
Competitive aggressiveness * SKM & 0.071 & 0.349 & 0.059 & 0.451 \\
Capability & & & &
\end{tabular}

Note: Coefficient is significant at $* * p<0.05, * * * p<0.01$

Table V. Missing variables endogeneity analysis

\begin{tabular}{|c|c|c|c|c|c|c|c|c|}
\hline \multirow[t]{2}{*}{ Explaining variables } & \multicolumn{4}{|c|}{ Explained variable: competitive advantage } & \multicolumn{4}{|c|}{ Explained variable: firm performance } \\
\hline & M1 & M2 & M3 & M4 & M1 & M2 & M3 & M4 \\
\hline Firm age & 0.006 & 0.019 & 0.013 & 0.017 & 0.071 & 0.002 & 0.008 & 0.019 \\
\hline Firm size & 0.020 & 0.031 & 0.018 & 0.016 & 0.013 & 0.018 & 0.011 & 0.012 \\
\hline Environmental dynamism & 0.011 & 0.019 & 0.024 & 0.031 & 0.016 & 0.018 & 0.011 & 0.010 \\
\hline Munificence & 0.154 & 0.029 & 0.012 & 0.010 & 0.012 & 0.004 & 0.015 & 0.021 \\
\hline $\begin{array}{l}\text { Number of family member } \\
\text { ownership }\end{array}$ & 0.037 & 0.049 & 0.038 & 0.027 & 0.018 & 0.014 & 0.025 & 0.023 \\
\hline Innovation speed & 0.014 & 0.013 & 0.015 & 0.026 & 0.026 & 0.013 & 0.016 & 0.019 \\
\hline Innovativeness & & $0.231 * * *$ & & $0.269 * *$ & & $0.324 * * *$ & & $0.237 * * *$ \\
\hline Proactiveness & & $0.359 * * *$ & & $0.227 * *$ & & $0.427 * * *$ & & $0.225 * *$ \\
\hline Risk-taking & & $0.103 * *$ & & $0.141 *$ & & $0.178 * *$ & & $0.119 *$ \\
\hline Autonomy & & 0.030 & & 0.039 & & 0.725 & & 0.031 \\
\hline $\begin{array}{l}\text { Competitive } \\
\text { aggressiveness }\end{array}$ & & 0.021 & & 0.013 & & 0.738 & & 0.024 \\
\hline SKM capability & & & $0.461 * * *$ & $0.117 * *$ & & & $0.563 * * *$ & $0.424 * *$ \\
\hline Innovativeness * SKM & & & & $0.516 * * *$ & & & & $0.444 * * *$ \\
\hline Proactiveness * SKM & & & & $0.458 * * *$ & & & & $0.326 * *$ \\
\hline Risk-taking * SKM & & & & $0.159 * *$ & & & & $0.142 *$ \\
\hline Autonomy * SKM & & & & 0.035 & & & & 0.014 \\
\hline $\begin{array}{l}\text { Competitive } \\
\text { aggressiveness * SKM }\end{array}$ & & & & 0.010 & & & & 0.010 \\
\hline$R^{2}$ & 0.255 & 0.119 & 0.127 & 0.166 & 0.091 & 0.195 & 0.162 & 0.177 \\
\hline Adjusted $R^{2}$ & 0.053 & 0.058 & 0.025 & 0.063 & 0.068 & 0.158 & 0.096 & 0.138 \\
\hline$\triangle R^{2}$ & & 0.017 & 0.011 & 0.014 & & 0.098 & 0.003 & 0.012 \\
\hline F-value & 0.68 & $1.625 * *$ & $1.810 * * *$ & $3.013 * * *$ & $1.649 *$ & $3.551 * *$ & $2.713 * *$ & $4.019 * * *$ \\
\hline
\end{tabular}


Table VI. Endogeneity test: Heckman Second-stage test

\begin{tabular}{|c|c|c|c|c|c|c|}
\hline \multirow[t]{2}{*}{ Explaining variables } & \multicolumn{3}{|c|}{ Explained variable: competitive advantage } & \multicolumn{3}{|c|}{ Explained variable: firm performance } \\
\hline & M1 & M2 & M3 & M1 & M2 & M3 \\
\hline Firm age & 0.039 & 0.008 & 0.003 & 0.003 & 0.033 & 0.012 \\
\hline Firm size & 0.019 & 0.012 & 0.017 & 0.059 & 0.024 & 0.013 \\
\hline Environmental dynamism & 0.203 & 0.025 & 0.202 & 0.017 & 0.043 & 0.023 \\
\hline Munificence & 0.011 & 0.026 & 0.071 & 0.039 & 0.022 & 0.018 \\
\hline $\begin{array}{l}\text { Number of family member } \\
\text { ownership }\end{array}$ & 0.027 & 0.025 & 0.031 & 0.016 & 0.021 & 0.013 \\
\hline Inverse Mills Ratio & 0.040 & 0.119 & 0.118 & 0.071 & 0.203 & 0.214 \\
\hline Innovativeness & & $0.251 * *$ & $0.211 * *$ & & $0.217 * *$ & $0.277 * *$ \\
\hline Proactiveness & & $0.379 * * *$ & $0.255^{* *}$ & & $0.387 * * *$ & $0.232 * *$ \\
\hline Risk-taking & & $0.148 *$ & $0.116^{*}$ & & $0.144 *$ & $0.145^{*}$ \\
\hline Autonomy & & 0.031 & 0.070 & & 0.056 & 0.070 \\
\hline Competitive aggressiveness & & 0.022 & 0.020 & & 0.067 & 0.062 \\
\hline Innovativeness * SKM & & & $0.370 * * *$ & & & $0.331 * * *$ \\
\hline Proactiveness * SKM & & & $0.242 * *$ & & & $0.297 * *$ \\
\hline Risk-taking * SKM & & & $0.175 * *$ & & & $0.171 * *$ \\
\hline Autonomy * SKM & & & 0.010 & & & 0.068 \\
\hline Competitive aggressiveness & & & 0.052 & & & 0.024 \\
\hline Wald chi ${ }^{2}$ & 0.217 & $22.03 * * *$ & $31.421 * *$ & 0.071 & $20.17 * * *$ & $23.04 * *$ \\
\hline Prob $>$ chi $^{2}$ & 0.418 & 0.001 & 0.023 & 0.624 & 0.008 & 0.029 \\
\hline
\end{tabular}

Note: SKM: strategic knowledge management capability

${ }^{*} \mathrm{p}<0.10,{ }^{*} \mathrm{p}<0.05, * * * \mathrm{p}<0.01$

Table VII. Endogeneity test: Entrepreneur's human capital as an instrumental variable

\begin{tabular}{|c|c|c|c|c|c|c|}
\hline \multirow[t]{2}{*}{ Explaining variables } & \multicolumn{3}{|c|}{ Explained variable: competitive advantage } & \multicolumn{3}{|c|}{ Explained variable: firm performance } \\
\hline & M1 & M2 & M3 & M1 & M2 & M3 \\
\hline Controls & Yes & Yes & Yes & Yes & Yes & Yes \\
\hline Innovativeness & $0.271 * *$ & & & $0.231 * *$ & & \\
\hline Proactiveness & $0.367 * * *$ & & & $0.346 * * *$ & & \\
\hline Risk-taking & $0.141^{*}$ & & & $0.161 *$ & & \\
\hline Autonomy & 0.055 & & & 0.042 & & \\
\hline Competitive aggressiveness & 0.043 & & & 0.027 & & \\
\hline SKM capability & & 0.462 & & & $0.409 * * *$ & \\
\hline Innovativeness * SKM & & & $0.343 * * *$ & & & $0.341 * * *$ \\
\hline Proactiveness $*$ SKM & & & $0.256^{* *}$ & & & $0.256 * *$ \\
\hline Risk-taking * SKM & & & $0.112 *$ & & & $0.117 *$ \\
\hline Autonomy * SKM & & & 0.043 & & & 0.045 \\
\hline $\begin{array}{l}\text { Competitive aggressiveness * } \\
\text { SKM }\end{array}$ & & & 0.031 & & & 0.058 \\
\hline Partial $R^{2}$ & 0.012 & 0.010 & 0.009 & 0.021 & 0.004 & 0.006 \\
\hline Partial $R^{2}: \mathrm{F}$ & 8.955 & 2.038 & 1.507 & 8.119 & 2.863 & 1.318 \\
\hline Hausman test & $3.801 * *$ & $1.411 *$ & $2.912 * *$ & $3.789 * *$ & $1.761 *$ & $2.204 * *$ \\
\hline Adj $-R^{2}$ & 0.016 & 0.004 & 0.002 & 0.006 & 0.002 & -0.007 \\
\hline Observations & 268 & 268 & 268 & 268 & 268 & 268 \\
\hline
\end{tabular}

Note: SKM: strategic knowledge management capability

$* \mathrm{p}<0.10, * * \mathrm{p}<0.05, * * * \mathrm{p}<0.01$ 
Table VIII. RMSE values during training and testing stages

\begin{tabular}{|c|c|c|c|c|c|c|c|c|c|c|c|c|c|c|c|c|}
\hline \multirow{3}{*}{$\begin{array}{l}\text { Neural } \\
\text { networks }\end{array}$} & \multicolumn{4}{|c|}{ Model A $\left(\mathrm{R}^{2}=53.59 \%\right)$} & \multicolumn{4}{|c|}{ Model B $\left(\mathrm{R}^{2}=58.16 \%\right)$} & \multicolumn{4}{|c|}{ Model C $\left(\mathrm{R}^{2}=64.37 \%\right)$} & \multicolumn{4}{|c|}{ Model D $\left(\mathrm{R}^{2}=66.42 \%\right)$} \\
\hline & \multicolumn{2}{|c|}{ Training } & \multicolumn{2}{|c|}{ Testing } & \multicolumn{2}{|c|}{ Training } & \multicolumn{2}{|c|}{ Testing } & \multicolumn{2}{|c|}{ Training } & \multicolumn{2}{|c|}{ Testing } & \multicolumn{2}{|c|}{ Training } & \multicolumn{2}{|c|}{ Testing } \\
\hline & $\mathrm{N}$ & RMSE & $\mathrm{N}$ & RMSE & $\mathrm{N}$ & RMSE & $\mathrm{N}$ & RMSE & $\mathrm{N}$ & RMSE & $\mathrm{N}$ & RMSE & $\mathrm{N}$ & RMSE & $\mathrm{N}$ & RMSE \\
\hline First & 239 & 0.107 & 29 & 0.099 & 239 & 0.077 & 29 & 0.083 & 241 & 0.070 & 27 & 0.060 & 240 & 0.069 & 28 & 0.056 \\
\hline Second & 244 & 0.101 & 24 & 0.104 & 244 & 0.070 & 24 & 0.066 & 234 & 0.078 & 34 & 0.051 & 246 & 0.069 & 22 & 0.064 \\
\hline Third & 243 & 0.098 & 25 & 0.084 & 243 & 0.070 & 25 & 0.060 & 240 & 0.074 & 28 & 0.061 & 240 & 0.066 & 28 & 0.059 \\
\hline Fourth & 237 & 0.114 & 31 & 0.111 & 237 & 0.069 & 31 & 0.072 & 229 & 0.079 & 39 & 0.067 & 240 & 0.061 & 28 & 0.069 \\
\hline Fifth & 233 & 0.097 & 35 & 0.106 & 233 & 0.075 & 35 & 0.069 & 244 & 0.076 & 24 & 0.061 & 244 & 0.067 & 24 & 0.067 \\
\hline Sixth & 240 & 0.094 & 28 & 0.122 & 240 & 0.071 & 28 & 0.061 & 236 & 0.070 & 32 & 0.059 & 250 & 0.069 & 18 & 0.061 \\
\hline Seventh & 237 & 0.101 & 31 & 0.115 & 237 & 0.072 & 31 & 0.060 & 237 & 0.067 & 31 & 0.050 & 250 & 0.064 & 18 & 0.060 \\
\hline Eighth & 243 & 0.114 & 25 & 0.113 & 243 & 0.073 & 25 & 0.069 & 248 & 0.067 & 20 & 0.066 & 234 & 0.062 & 34 & 0.063 \\
\hline Ninth & 240 & 0.102 & 28 & 0.097 & 240 & 0.071 & 28 & 0.061 & 234 & 0.061 & 34 & 0.067 & 248 & 0.062 & 20 & 0.064 \\
\hline Tenth & 241 & 0.102 & 27 & 0.071 & 241 & 0.071 & 27 & 0.068 & 238 & 0.066 & 30 & 0.049 & 241 & 0.069 & 27 & 0.064 \\
\hline Average & & 0.103 & & 0.102 & & 0.072 & & 0.067 & & 0.071 & & 0.059 & & 0.066 & & 0.062 \\
\hline Std. d. & & 0.0067 & & 0.0153 & & 0.0024 & & 0.0071 & & 0.0058 & & 0.0069 & & 0.0033 & & 0.0039 \\
\hline
\end{tabular}

Table IX.a. Sensitivity analysis (Direct model)

\begin{tabular}{|c|c|c|c|c|c|c|c|c|c|c|c|c|}
\hline \multirow{2}{*}{$\begin{array}{l}\text { Neural } \\
\text { networks }\end{array}$} & \multicolumn{5}{|c|}{ Model A (competitive advantage) } & \multicolumn{5}{|c|}{ Model B (firm performance) } & \multirow[b]{2}{*}{ SKM } & \multirow[b]{2}{*}{$\mathrm{CA}$} \\
\hline & Innovativeness & Proactiveness & $\begin{array}{c}\text { Risk- } \\
\text { taking }\end{array}$ & $\begin{array}{c}\text { Competitive } \\
\text { aggressiveness }\end{array}$ & Autonomy & Innovativeness & Proactiveness & $\begin{array}{c}\text { Risk- } \\
\text { taking }\end{array}$ & $\begin{array}{c}\text { Competitive } \\
\text { aggressiveness }\end{array}$ & Autonomy & & \\
\hline First & 0.291 & 0.376 & 0.112 & 0.072 & 0.089 & 0.129 & 0.309 & 0.024 & 0.015 & 0.078 & 0.289 & 0.228 \\
\hline Second & 0.372 & 0.494 & 0.084 & 0.014 & 0.036 & 0.122 & 0.393 & 0.079 & 0.055 & 0.034 & 0.217 & 0.222 \\
\hline Third & 0.344 & 0.339 & 0.114 & 0.08 & 0.123 & 0.097 & 0.339 & 0.067 & 0.024 & 0.062 & 0.156 & 0.255 \\
\hline Fourth & 0.348 & 0.389 & 0.109 & 0.044 & 0.11 & 0.085 & 0.369 & 0.057 & 0.019 & 0.079 & 0.221 & 0.271 \\
\hline Fifth & 0.304 & 0.423 & 0.104 & 0.043 & 0.126 & 0.09 & 0.338 & 0.079 & 0.056 & 0.039 & 0.145 & 0.254 \\
\hline Sixth & 0.281 & 0.43 & 0.089 & 0.088 & 0.111 & 0.041 & 0.386 & 0.049 & 0.044 & 0.062 & 0.194 & 0.223 \\
\hline Seventh & 0.302 & 0.404 & 0.166 & 0.056 & 0.073 & 0.083 & 0.389 & 0.057 & 0.021 & 0.062 & 0.258 & 0.139 \\
\hline Eighth & 0.285 & 0.411 & 0.106 & 0.078 & 0.12 & 0.047 & 0.324 & 0.098 & 0.027 & 0.078 & 0.281 & 0.218 \\
\hline Ninth & 0.302 & 0.552 & 0.079 & 0.048 & 0.019 & 0.101 & 0.343 & 0.068 & 0.027 & 0.05 & 0.266 & 0.159 \\
\hline Tenth & 0.223 & 0.514 & 0.076 & 0.075 & 0.112 & 0.074 & 0.388 & 0.066 & 0.037 & 0.071 & 0.243 & 0.165 \\
\hline Average & 0.305 & 0.433 & 0.104 & 0.060 & 0.092 & 0.087 & 0.358 & 0.064 & 0.033 & 0.062 & 0.227 & 0.213 \\
\hline $\begin{array}{l}\text { Normalized } \\
\text { importance }\end{array}$ & 77.3 & 100 & 29.8 & 19.2 & 23.3 & 38.07 & 100.00 & 29.47 & 7.43 & 27.32 & 72.60 & 64.31 \\
\hline
\end{tabular}


Table IX.b. Sensitivity analysis (Contingency model)

\begin{tabular}{|c|c|c|c|c|c|c|c|c|c|c|c|c|c|}
\hline \multirow{2}{*}{$\begin{array}{l}\text { Neural } \\
\text { networks }\end{array}$} & \multicolumn{6}{|c|}{ Model C (competitive advantage) } & \multicolumn{7}{|c|}{ Model D (firm performance ) } \\
\hline & $\begin{array}{l}\text { Innovativeness } \\
* \text { SKM }\end{array}$ & $\begin{array}{l}\text { Proactiveness } \\
\text { *SKM }\end{array}$ & $\begin{array}{l}\text { Risk-taking } \\
\text { *SKM }\end{array}$ & $\begin{array}{l}\text { Competitive } \\
\text { aggressiveness } \\
\text { *SKM }\end{array}$ & $\begin{array}{l}\text { Autonomy } \\
\text { *SKM }\end{array}$ & SKM & $\begin{array}{l}\text { Innovativeness } \\
* \text { SKM }\end{array}$ & $\begin{array}{l}\text { Proactiveness } \\
\text { *SKM }\end{array}$ & $\begin{array}{l}\text { Risk-taking } \\
* \text { SKM }\end{array}$ & $\begin{array}{l}\text { Competitive } \\
\text { aggressiveness } \\
\text { *SKM }\end{array}$ & $\begin{array}{l}\text { Autonomy } \\
* \text { SKM }\end{array}$ & SKM & $\mathrm{CA}$ \\
\hline First & 0.293 & 0.286 & 0.136 & 0.084 & 0.080 & 0.193 & 0.263 & 0.236 & 0.115 & 0.068 & 0.014 & 0.104 & 0.201 \\
\hline Second & 0.233 & 0.222 & 0.186 & 0.114 & 0.108 & 0.136 & 0.353 & 0.264 & 0.117 & 0.074 & 0.063 & 0.167 & 0.189 \\
\hline Third & 0.241 & 0.239 & 0.226 & 0.059 & 0.050 & 0.185 & 0.315 & 0.241 & 0.112 & 0.08 & 0.022 & 0.164 & 0.233 \\
\hline Fourth & 0.285 & 0.162 & 0.197 & 0.009 & 0.140 & 0.207 & 0.407 & 0.253 & 0.115 & 0.083 & 0.074 & 0.196 & 0.273 \\
\hline Fifth & 0.271 & 0.149 & 0.177 & 0.141 & 0.133 & 0.183 & 0.366 & 0.292 & 0.201 & 0.06 & 0.088 & 0.112 & 0.18 \\
\hline Seventh & 0.232 & 0.184 & 0.315 & 0.039 & 0.022 & 0.109 & 0.354 & 0.268 & 0.161 & 0.081 & 0.011 & 0.128 & 0.206 \\
\hline Eighth & 0.164 & 0.232 & 0.156 & 0.133 & 0.114 & 0.202 & 0.378 & 0.276 & 0.169 & 0.073 & 0.033 & 0.121 & 0.161 \\
\hline Ninth & 0.335 & 0.192 & 0.108 & 0.021 & 0.062 & 0.203 & 0.267 & 0.214 & 0.117 & 0.032 & 0.076 & 0.121 & 0.16 \\
\hline Tenth & 0.286 & 0.109 & 0.175 & 0.161 & 0.060 & 0.239 & 0.426 & 0.283 & 0.197 & 0.051 & 0.023 & 0.183 & 0.167 \\
\hline Average & 0.258 & 0.200 & 0.183 & 0.089 & 0.087 & 0.181 & 0.350 & 0.260 & 0.158 & 0.065 & 0.043 & 0.145 & 0.193 \\
\hline $\begin{array}{l}\text { Normalized } \\
\text { importance }\end{array}$ & 100.00 & 63.20 & 61.60 & 29.60 & 22.50 & 59.40 & 100.00 & 68.70 & 22.70 & 11.90 & 6.40 & 49.40 & 57.10 \\
\hline
\end{tabular}


Figure 1. Moderating effect of SKM capability on the relationship between innovativeness and competitive advantage (95\% confidence interval (0.2325-0.4639))

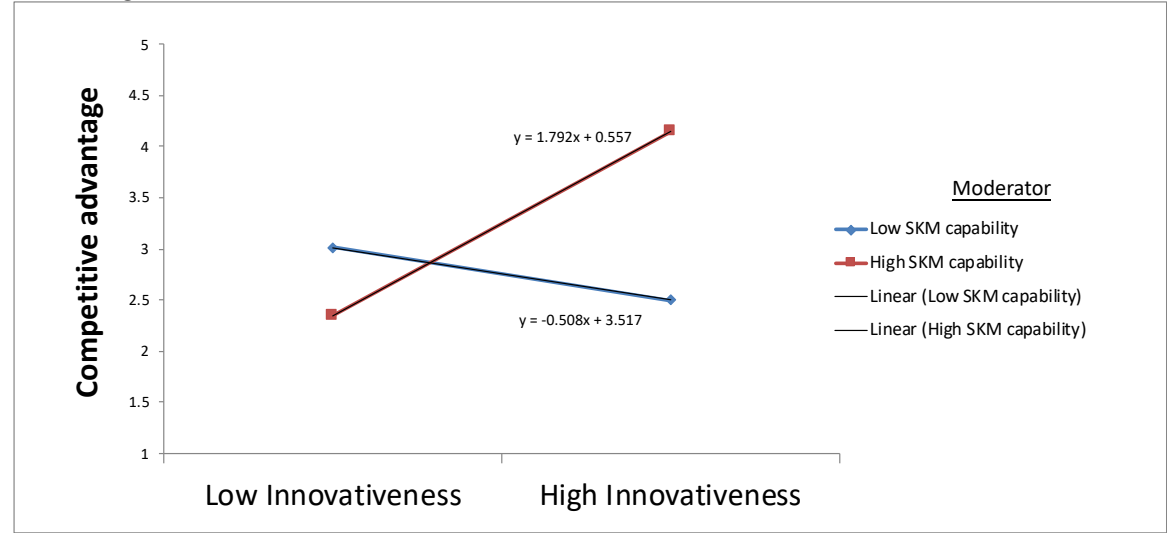

Figure 2. Moderating effect of SKM capability on the relationship between proactiveness and competitive advantage (95\% confidence interval (0.2301-0.4123))

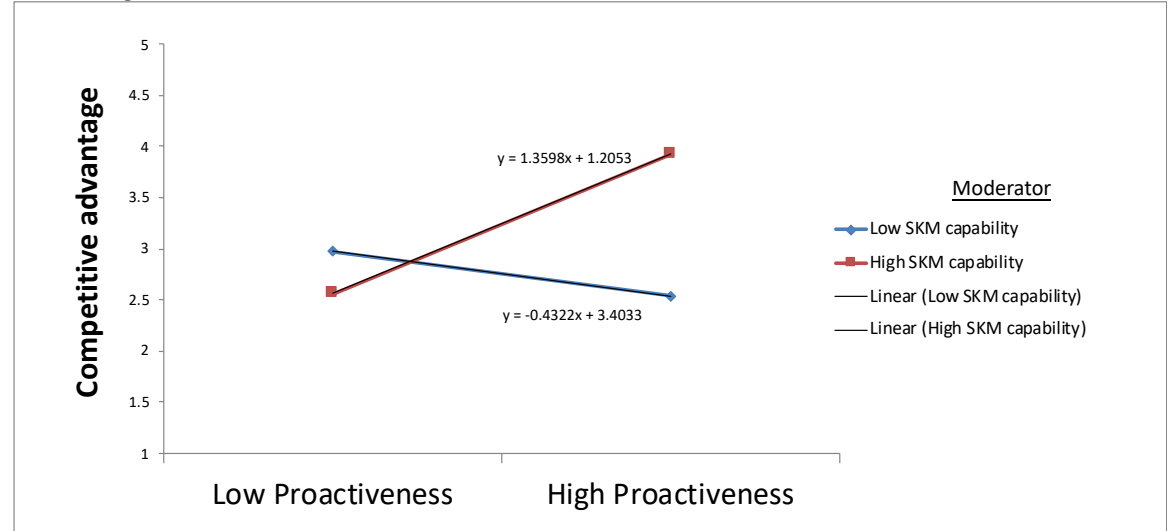

Figure 3. Moderating effect of SKM capability on the relationship between risk-taking attitude and competitive advantage (95\% confidence interval (0.1751-0.3628))

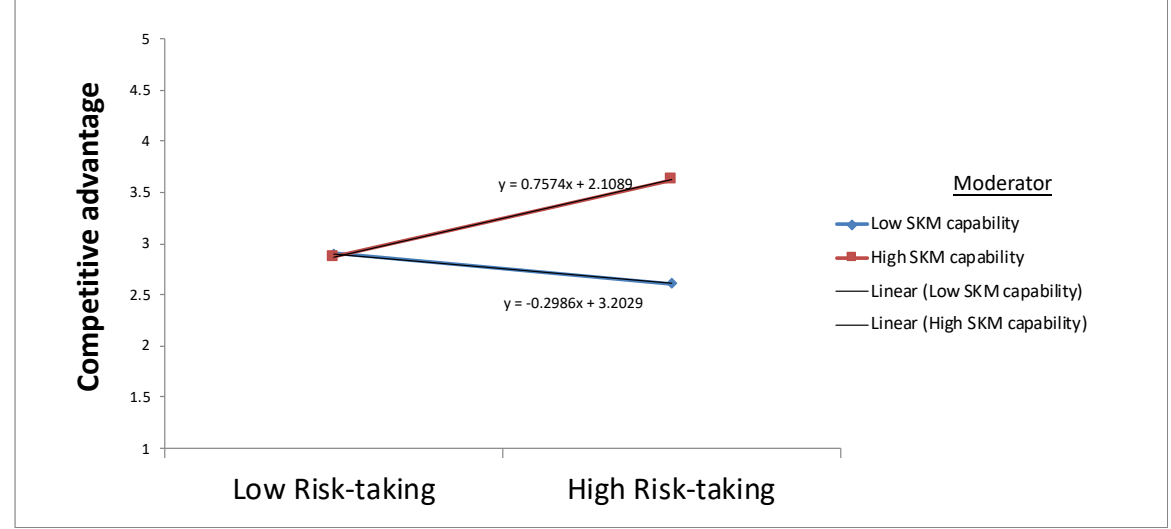


Figure 4. Moderating effect of SKM capability on the relationship between innovativeness and firm performance (95\% confidence interval (0.3539-0.5616))

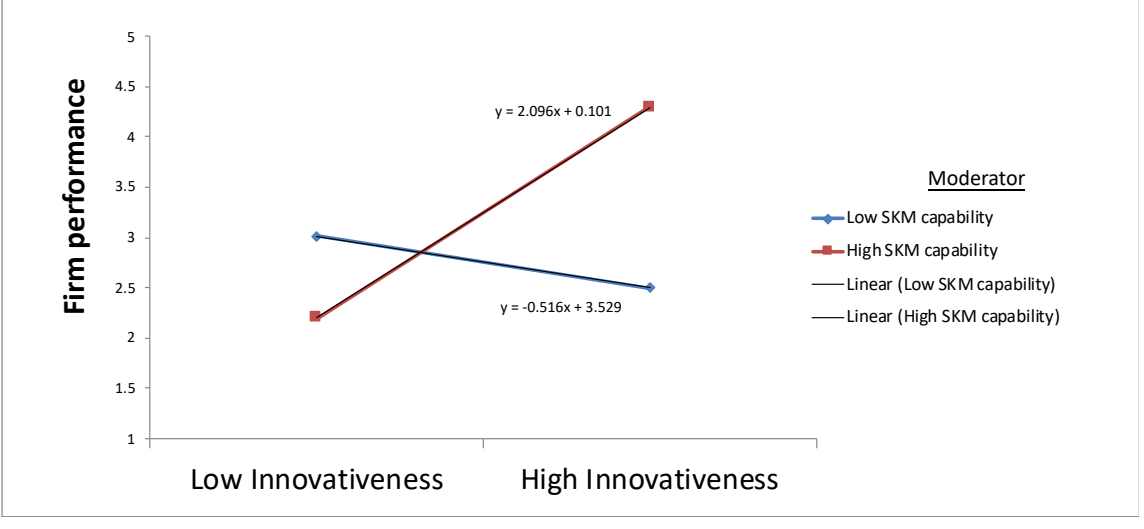

Figure 5. Moderating effect of SKM capability on the relationship between proactiveness and firm performance (95\% confidence interval (0.2719-0.4139))

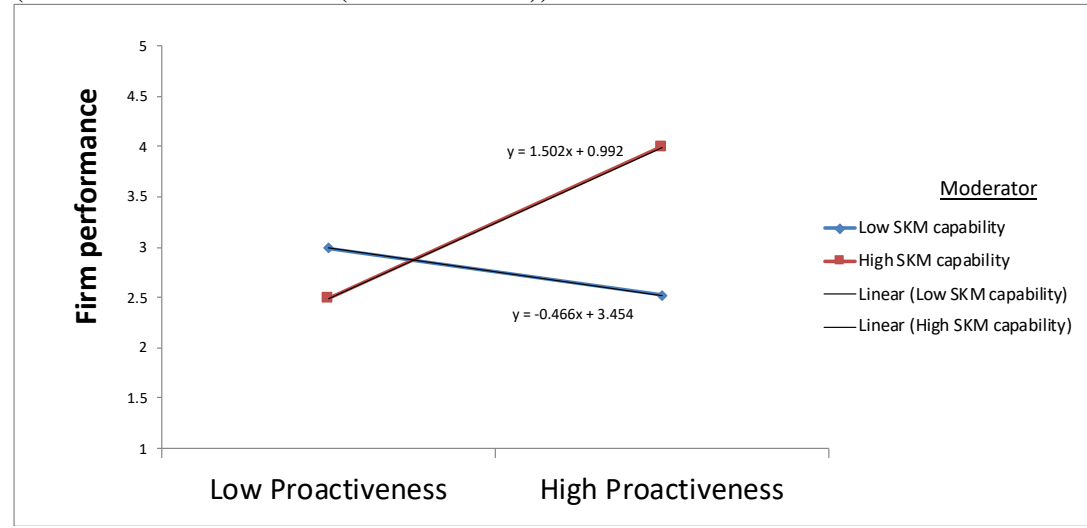

Figure 6. Moderating effect of SKM capability on the relationship between risk-taking attitude and firm performance (95\% confidence interval (0.1163-0.2372))

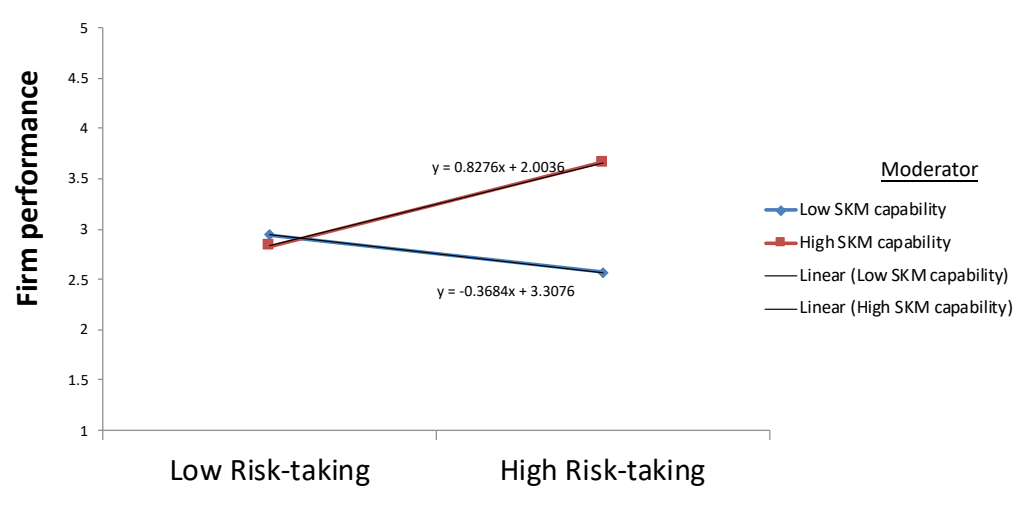


Figure 7. DL-AI Model A

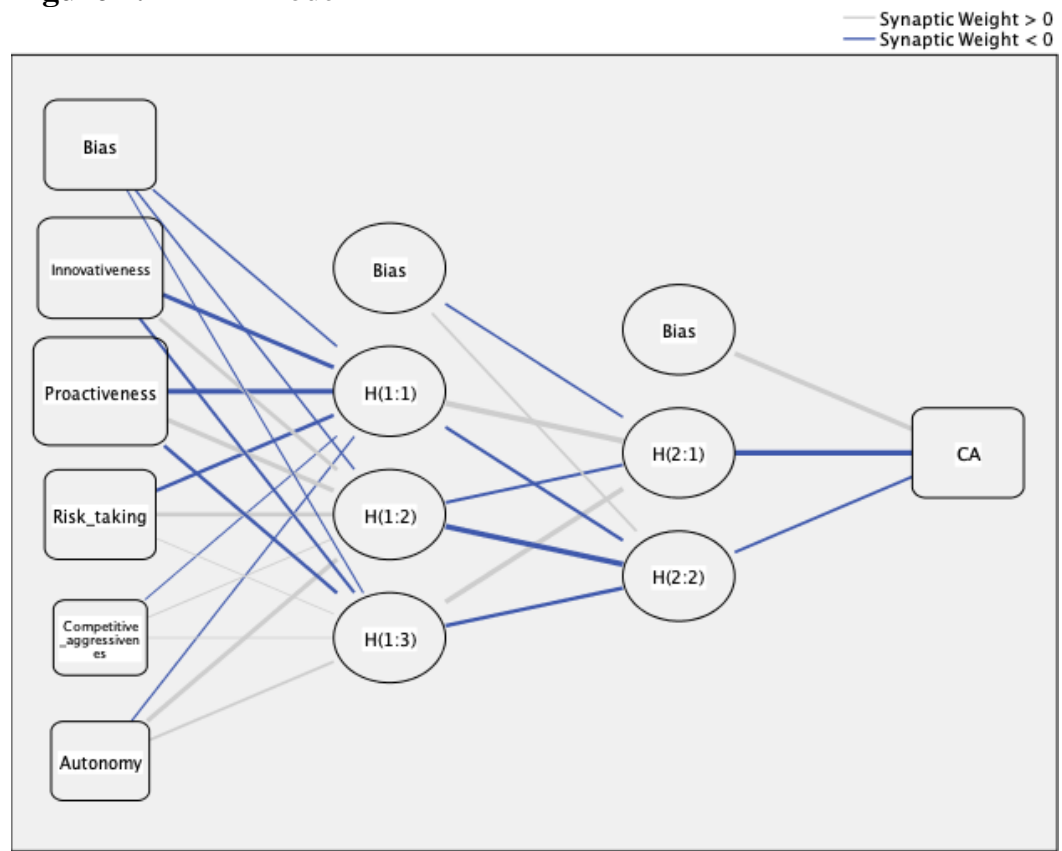

Hidden layer activation function: Sigmoid

Output layer activation function: Sigmoid

Figure 8. DL-AI Model B

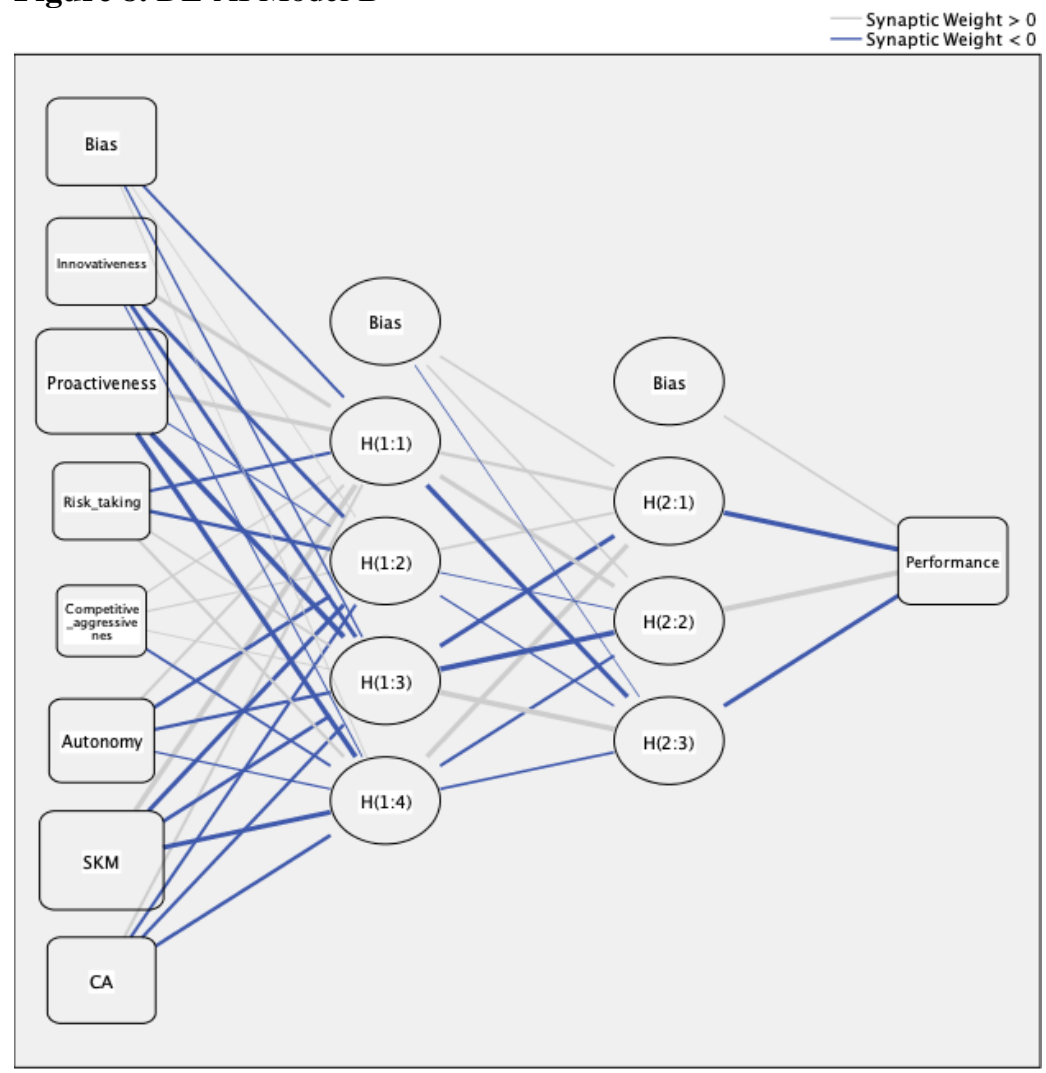

Hidden layer activation function: Sigmoid

Output layer activation function: Sigmoid 
Figure 9. DL-AI Model C

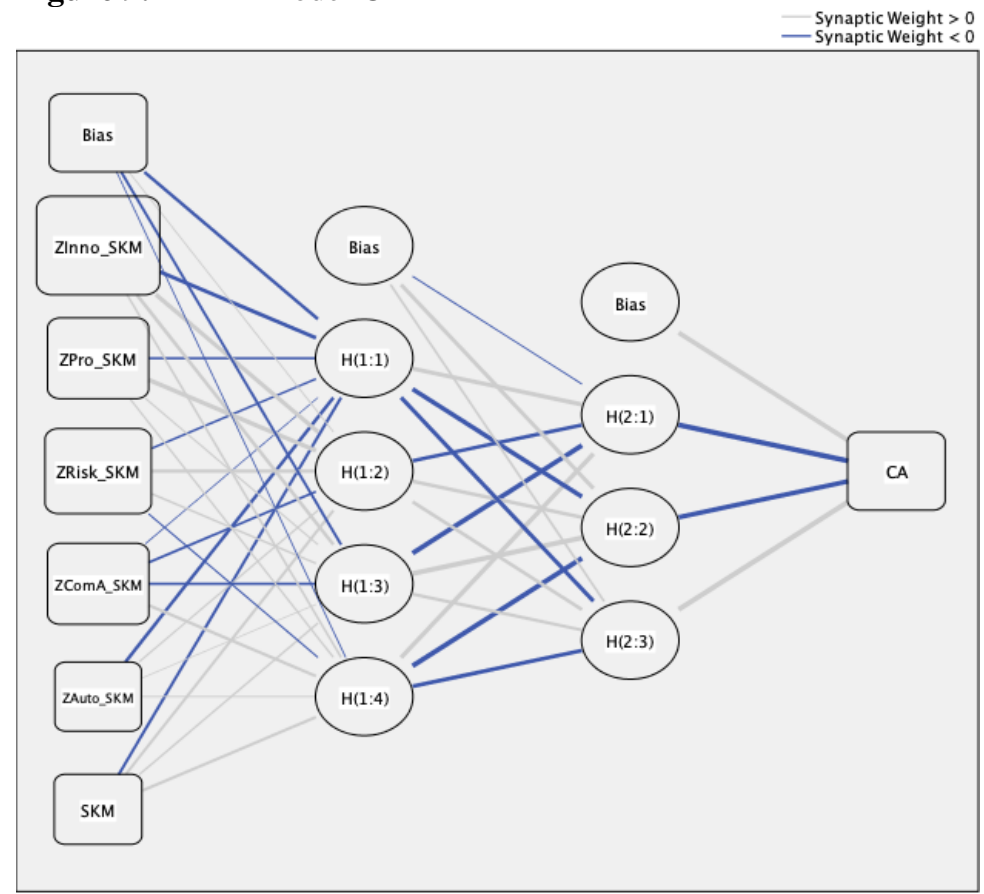

Hidden layer activation function: Sigmoid

Output layer activation function: Sigmoid

Figure 10. DL-AI Model D

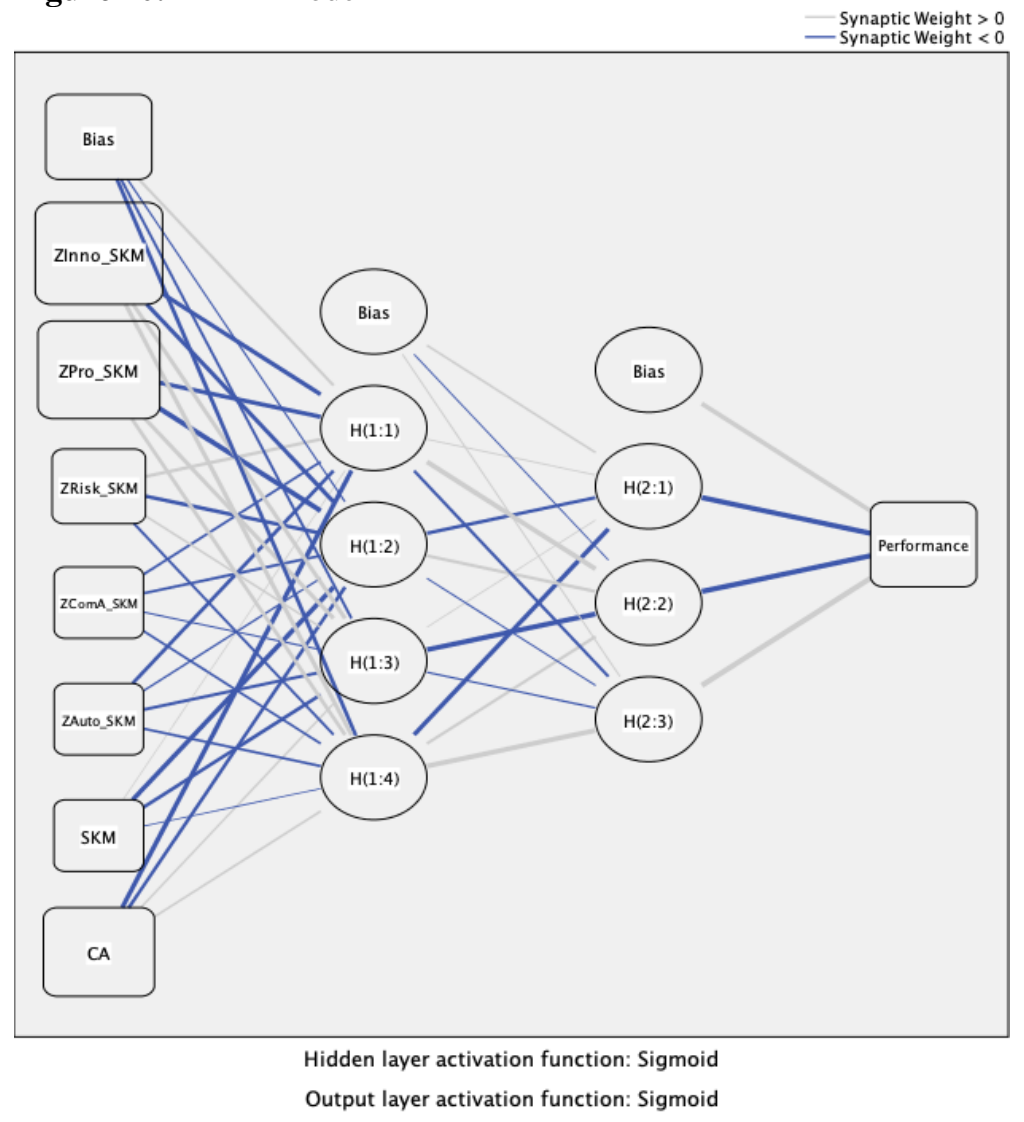


Appendix 1. Demographics

\begin{tabular}{lc}
\hline Legends & Frequency \\
\hline Number of employees & \\
$10-30$ & 52 \\
$31-50$ & 84 \\
$51-70$ & 78 \\
$71-90$ & 54 \\
Firm age & \\
$1-4$ & 39 \\
$5-8$ & 107 \\
$9-12$ & 93 \\
$13-$ above & 29 \\
Industry & \\
Manufacturing & \\
Aero components & 3 \\
Automotive components & 28 \\
Chemicals, minerals \& alloys & 31 \\
Computer components & 19 \\
Machinery \& equipment & 33 \\
Pharmaceuticals & 38 \\
Services & \\
Business consultancy & 29 \\
Constructions & 8 \\
Engineering services & 28 \\
Financial & 21 \\
IT and software services & 18 \\
Data processing & 12 \\
\hline
\end{tabular}

\section{Appendix 2. Constructs and their properties}

\begin{tabular}{|c|c|}
\hline Constructs (items) & $\begin{array}{r}\text { Standard loa } \\
(n=268\end{array}$ \\
\hline \multicolumn{2}{|l|}{ Entrepreneurial orientation } \\
\hline \multicolumn{2}{|l|}{ Innovativeness $(\alpha=0.792, \mathrm{CR}=0.786, \mathrm{AVE}=0.587, \mathrm{MSV}: 0.204)$} \\
\hline 1. Our firm is known as an innovator among businesses in our industry. & 0.728 \\
\hline 2. Our firm promotes new, innovative product/services. & 0.720 \\
\hline 3. Our firm provides leadership in developing new products/services. & 0.752 \\
\hline 4. Our firm is constantly experimenting with new products/services. & 0.742 \\
\hline 5. Our firm has built a reputation for being the best in the industry to develop new methods and technologies. & 0.729 \\
\hline \multicolumn{2}{|l|}{ Risk-taking attitude $(\alpha=0.727, \mathrm{CR}=0.717, \mathrm{AVE}=0.518, \mathrm{MSV}: 0.161)$} \\
\hline 1. Our firm tends to invest in high-risk projects. & 0.731 \\
\hline 2. This firm shows a great deal of tolerance for high risk projects. & 0.852 \\
\hline 3. Our business strategy is characterized by a strong tendency to take risks. & 0.726 \\
\hline \multicolumn{2}{|l|}{ Proactiveness $(\alpha=0.775, \mathrm{CR}=0.739, \mathrm{AVE}=0.506, \mathrm{MSV}: 0.212)$} \\
\hline 1. Our firm seeks to exploit anticipated changes in our target market ahead of our rivals. & 0.765 \\
\hline 2. Our firm seizes initiatives whenever possible in our target market operations. & 0.699 \\
\hline 3. Our firm acts opportunistically to shape the business environment in which we operate. & 0.783 \\
\hline \multicolumn{2}{|l|}{ Competitive aggressiveness $(\alpha=0.820, \mathrm{CR}=0.770, \mathrm{AVE}=0.532, \mathrm{MSV}: 0.230)$} \\
\hline 1. Our firm typically adopts an "undo-the-competitor" posture in our target markets. & 0.780 \\
\hline 2. Our firm takes hostile steps to achieve competitive goals in our target markets. & 0.781 \\
\hline 3. Our actions toward competitors can be termed as aggressive. & 0.730 \\
\hline
\end{tabular}


1. Our firm behave autonomously in our business operations.

2. Our firm act independently to carry out their business ideas through to completion.

0.733

3. Our firm is self-directed in pursuit of target market opportunities.

Strategic knowledge management capability $(\alpha=0.702, \mathrm{CR}=0.754$, AVE $=0.509$, MSV: 0.133$)$

1. Our strategy is formulated and updated based on company knowledge and competencies.

2. Our strategy addresses the development of knowledge and competencies.

3. We systematically compares its strategic knowledge and competence to that of its competitors.

4. Our firm has knowledge and competence management strategy which is communicated to employees clearly and comprehensively.

0.792

5. The responsibility for strategic knowledge management has been clearly assigned to specific personnel.

Competitive advantage $(\alpha=0.747, \mathrm{CR}=0.760, \mathrm{AVE}=0.508, \mathrm{MSV}: 0.238)$

Price/cost

1. Our firm offers competitive price.

0.745

2. Our firm is able to offer price as low or lower than our competitors.

Quality

1. Our firm is able to compete based on quality.

0.762

2. Our firm offers products/service that are highly reliable.

0.772

3. Our firm offers products/service that are very durable.

0.773

4. Our firm offers high quality products/service to our customers.

0.796

Dependability

1. Our firm deliver the kind of products/services needed by consumers

2. Our firm delivers product/services on time

0.779

3. Our firm provides dependable delivery

Customization

1. Our firm provides bespoke solutions.

2. Our firm customize products/service offerings to meet client needs.

0.723

3. Our firm Respond well to customer demand for 'new' features.

Time-to-market

1. We introduce products/service first in the market.

0.796

2. We delivers products/services to market quickly.

0.728

3. Our time-to-market lower than industry average.

0.786

4. We have quick products/services development process.

Firm performance $(\alpha=0.872, \mathrm{CR}=0.732, \mathrm{AVE}=0.561$, MSV: 0.255$)$

Profitability

$\begin{array}{lr}\text { 1. Company overall profitability. } & 0.817\end{array}$

$\begin{array}{lr}\text { 2. Company return on investment. } & 0.706\end{array}$

$\begin{array}{lr}3 . \text { Company return on asset. } & 0.714\end{array}$

Sales performance

$\begin{array}{ll}\text { 1. Overall market share relative to target market objective. } & 0.733\end{array}$

2. Sales volumes relative to target market objective. $\quad 0.742$

$\begin{array}{lr}\text { 3. Sales growth relative to target market objective. } & 0.718\end{array}$ 